\title{
Article \\ Genetic Analysis of Early White Quality Protein Maize Inbreds and Derived Hybrids under Low-Nitrogen and Combined Drought and Heat Stress Environments
}

\author{
Olatunde A. Bhadmus ${ }^{1,2}\left(\mathbb{D}\right.$, Baffour Badu-Apraku $^{2, *}{ }^{\mathbb{D}}$, Oyenike A. Adeyemo $^{1}$ and Adebayo L. Ogunkanmi ${ }^{1}$ \\ 1 Department of Cell Biology and Genetics, University of Lagos, Lagos 101017, Nigeria; \\ azeezolatunde@yahoo.com (O.A.B.); aoadeyemo@unilag.edu.ng (O.A.A.); \\ adebayoogunkanmi@yahoo.com (A.L.O.) \\ 2 International Institute of Tropical Agriculture, IITA, PMB 5320 Oyo Road, Ibadan 200001, Nigeria \\ * Correspondence: b.badu-apraku@cgiar.org
}

\section{check for}

updates

Citation: Bhadmus, O.A.; Badu-Apraku, B.; Adeyemo, O.A.; Ogunkanmi, A.L. Genetic Analysis of Early White Quality Protein Maize Inbreds and Derived Hybrids under Low-Nitrogen and Combined Drough and Heat Stress Environments. Plants 2021, 10, 2596. https://doi.org/ $10.3390 /$ plants10122596

Academic Editors: Grazia Maria Borrelli and Daniela Marone

Received: 22 October 2021

Accepted: 19 November 2021

Published: 26 November 2021

Publisher's Note: MDPI stays neutral with regard to jurisdictional claims in published maps and institutional affiliations.

Copyright: (c) 2021 by the authors. Licensee MDPI, Basel, Switzerland. This article is an open access article distributed under the terms and conditions of the Creative Commons Attribution (CC BY) license (https:// creativecommons.org/licenses/by/ $4.0 /)$.

\begin{abstract}
An increase in the average global temperature and drought is anticipated in sub-Saharan Africa (SSA) as a result of climate change. Therefore, early white quality protein maize (QPM) hybrids with tolerance to combined drought and heat stress (CDHS) as well as low soil nitrogen (lownitrogen) have the potential to mitigate the adverse effects of climate change. Ninety-six early QPM hybrids and four checks were evaluated in Nigeria for two years under CDHS, low-nitrogen, and in optimal environments. The objectives of this study were to determine the gene action conditioning grain yield, assess the performance of the early QPM inbred lines and identify high yielding and stable QPM hybrids under CDHS, low-nitrogen and optimal environment conditions. There was preponderance of the non-additive gene action over the additive in the inheritance of grain yield under CDHS environment conditions, while additive gene action was more important for grain yield in a low-nitrogen environment. TZEQI 6 was confirmed as an inbred tester under low $\mathrm{N}$ while TZEQI $113 \times$ TZEQI 6 was identified as a single-cross tester under low-nitrogen environments. Plant and ear aspects were the primary contributors to grain yield under CDHS and low-nitrogen environments. TZEQI $6 \times$ TZEQI 228 and the check TZEQI $39 \times$ TZEQI 44 were the highest yielding under each stress environment and across environments. Hybrid TZEQI $210 \times$ TZEQI 188 was the most stable across environments and should be tested on-farm and commercialized in SSA.
\end{abstract}

Keywords: QPM inbred lines; combined drought and heat stress; maize; low soil nitrogen; drought

\section{Introduction}

Maize (Zea mays L.) is an economically important annual cereal crop that is predicted to become the most important cereal crop in the world by 2025 [1]. The current global yield of maize is about 1.1 billion tons and production is projected to increase to over 1.4 billion tons by 2030 [1,2]. It is estimated that $50 \%$ of the total population of West and Central Africa (WCA) depends on maize as a staple food while a large proportion of the maize produced annually is used as raw materials for various alcoholic beverages, poultry and the livestock industries $[3,4]$. As a staple food crop of the sub-region, maize plays an important role in combating malnutrition. The normal endosperm maize has about $71 \%$ starch compared to the quality protein maize (QPM) which has 46\% lysine and 66\% tryptophan in addition to the $71 \%$ starch. The two amino acids supply provide about $70-73 \%$ of the requirement of the human body [4-6]. Early studies by Akuamoah- Boateng [7] on infants fed with QPM porridge revealed reduced growth stunting, fewer sick days, and healthier growth statistics than those fed with normal endosperm maize. Other studies by Mbuya et al. [8] and Panda et al. [9] reported that QPM could replace soybean in poultry feed production which could reduce the cost of animal feed.

In addition to the agro-ecological advantage, the savannas of SSA contribute to high maize productivity through high incoming solar radiation and reduced incidence of pests 
and diseases due to prevailing low humidity and low night temperature conditions $[4,10]$. However, tropical soils have low levels of organic matter and available nitrogen, resulting in nutrient-depleted soils which cause grain yield losses of up to $80 \%$ [11,12]. Thus, resourcepoor farmers constituting a large proportion of the maize producers in SSA can hardly afford mineral fertilizers due to the high cost of nitrogen-based fertilizers as well as the general non-availability of fertilizers $[4,13]$. Furthermore, climate change threatens the goal of achieving global food security and could have severe socio-economic consequences globally [14]. With the fast-increasing world population, maize production is expected to be significantly affected by the adverse impacts of climate change and could lead to a global food crisis with major impacts, particularly in SSA [15-18]. Although maize is well adapted and substantially utilized in the savannas of SSA, the concurrent incidence of abiotic stresses such as drought and high temperature during flowering could reduce the photosynthetic rate, accelerate leaf senescence, induce kernel abortion and ultimately cause drastic yield losses $[19,20]$. The combination of the two stresses could lead to a grain yield loss of more than 90\% during flowering and grain filling in maize [10,21-24].

According to Neate [25], $40 \%$ of the maize production areas in SSA will be unsuitable for cultivation of the available maize germplasm due to the threat posed by CDHS as well as lack of tolerance to low-nitrogen by 2030. A major challenge of maize breeders of the present generation is to develop maize cultivars with CDHS and low-nitrogen tolerance for the agroecological zones of SSA $[4,15]$. A number of early and extra-early maturing maize QPM hybrids with tolerance to Striga, low-nitrogen and drought stress have been developed by the International Institute of Tropical Agriculture Maize Improvement Program (IITAMIP) and commercialized in West and Central Africa (WCA) [4,26]. However, very little information is available on QPM maize hybrids with tolerance to CDHS. While several studies have been conducted on the improvement of maize varieties for tolerance to drought and heat stress separately, Cairns et al. [27] highlighted that tolerance to both stresses separately did not confer tolerance to CDHS and concluded that drought and heat stresses in maize were genetically different from tolerance to the individual stresses. This calls for the need for the development and commercialization of hybrids with CDHS and low-nitrogen tolerance for SSA to mitigate the adverse effects of these stresses on farmers, particularly the resource-poor farmers.

Maize breeding efforts in recent years have recorded significant successes in identifying lines that could be used as tolerance donors for breeding of cultivars with CDHS tolerance. Cairns et al. [15] identified donor lines among CIMMYT and IITA inbred lines possessing high levels of tolerance to CDHS that could be used for the development of outstanding hybrids. In another study, Meseka et al. [21] assessed the level of tolerance in existing drought tolerant hybrids under CDHS and reported an appreciable level of tolerance among the hybrids. Similarly, Nelimor et al. [22] assessed early maize landraces from Ghana, Burkina-Faso and Togo, and identified accessions that could be invaluable donors of tolerant alleles for hybrid development under CDHS conditions. However, very few reports are available on the genetic action regulating grain yield and other agronomic traits under CDHS.

Breeding of early white QPM maize hybrids with tolerance to CDHS and the information on the gene action involved in the inheritance, the combining ability and heterotic patterns of inbred lines in the IITA-MIP are crucial to their successful use for hybrid development and production [26,28]. A recent study by Chiuta and Mutengwa [24] reported the preponderance of the non-additive gene action in the inheritance of grain yield of subtropical QPM inbreds under CDHS suggesting that hybrid development could be adopted as an efficient and effective breeding strategy for the development of tolerant cultivars [26]. Contrarily, Nasser et al. [29] studied the combining ability of early maturing yellow maize inbreds and reported the importance of the additive gene action over the non-additive gene action in the inheritance of grain yield under CDHS. The inconsistencies in the reports on the relative importance of the additive and non-additive gene action in the inheritance of grain yield and other traits call for the need for further studies to confirm 
the type of gene action controlling grain yield and other agronomic traits in the newly developed early maize QPM inbred lines in the IITA-MIP. Additionally, several studies have reported the preponderance of additive gene action over non-additive gene action in the inheritance of grain yield under low-nitrogen conditions [12,30-32]. Contrarily, studies by Makumbi et al. [33] and Badu-Apraku et al. [26] reported that non-additive gene action conditioned the grain yield of maize hybrids under low-nitrogen, while Noelle et al. [34] reported that both additive and non-additive genetic action conditioned grain yield when soil nitrogen was low. These conflicting reports by researchers could be due to the severity of the low-nitrogen environments or the germplasm used in the studies. Consequently, there is a need to evaluate the gene action conditioning the inheritance of grain yield and other important traits under low-nitrogen environments using the newly developed early white QPM inbred lines of the IITA-MIP.

The availability and use of early white QPM hybrids with tolerance to CDHS and low-nitrogen conditions would be more sustainable for smallholder farmers in nitrogendepleted areas of SSA where low levels of agricultural inputs are utilized and there is simultaneous incidence of drought and heat stresses [4]. Therefore, the objectives of this study were to: (a) investigate the gene action conditioning grain yield and other agronomic traits of early white QPM inbred lines under CDHS, low-nitrogen, as well as optimal growing environments; (b) group the inbred lines into heterotic groups using the heterotic grouping method based on the combining ability of multiple traits (HGCAMT) and identify inbred and single-cross testers; (c) assess the performance of the QPM inbred lines in hybrid combinations and identify high yielding and stable QPM hybrids under CDHS, low-nitrogen and across test environments.

\section{Results}

\subsection{Analysis of Variance of Agronomic Traits}

Under the CDHS environments, the analysis of variance (ANOVA) revealed significant $(p<0.01)$ variations among environment $(E)$ and genotype $(G)$ mean squares for the measured traits except for $E$ mean squares for plant height and $G$ mean squares for anthesis-silking interval (ASI) and plant height. Significant differences for genotype by environment interaction (GEI) mean squares were also observed for measured traits except for plant and ear heights (Table 1). Partitioning the hybrid components of variation into male(set) (GCAm), female(set) (GCAf) and female $\times$ male(set) (SCA) mean squares, GCAm and GCAf revealed significant differences in mean squares for most measured traits except GCAm effect for grain yield, ASI, plant height, plant and ear aspects as well as GCAf effect for ASI, plant height, ear aspect and tassel blasting. Additionally, significant SCA effects were observed for grain yield, days to $50 \%$ anthesis, ear height and tassel blasting. Significant differences were observed for GCAf and SCA and in their interaction with E for grain yield, days to $50 \%$ silking and the stay green characteristic. Broad sense heritability estimates ranged from $26 \%$ for the stay green characteristic to $74 \%$ for ear height while grain yield recorded $37 \%$. In general, low to high $\mathrm{H}^{2}$ estimates were observed for the measured traits. Moderately high repeatability estimates were recorded for measured traits under CDHS.

Across the low-nitrogen environments, the ANOVA revealed significant $(P<0.01)$ differences in mean squares for E, G and GEI for grain yield and other measured traits except G mean squares for ASI and plant aspect and GEI mean squares for ASI (Table 1). Significant differences were observed for GCAm and GCAf mean squares for measured traits except GCAm mean squares for ear height, ear aspect and the stay green characteristic as well as GCAf mean squares for ASI and ear height. No significant SCA mean squares were observed for measured traits. Additionally, significant differences in GCAf mean squares and the interactions with the environment were observed for grain yield, plant, and ear aspects. Broad sense heritability estimates ranged from $12 \%$ for ear aspect to $52 \%$ for plant height. Grain yield had $\mathrm{H}^{2}$ estimate of $37 \%$. Generally, very low $\mathrm{H}^{2}$ estimates were observed for the measured traits. Repeatability estimates of the measured traits were generally high for all locations. Consequently, the data for all locations were included in the analysis of variance. 


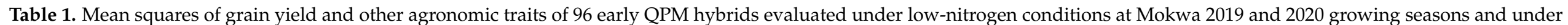
CDHS at Kadawa during the 2020 and 2021 dry seasons.

\begin{tabular}{|c|c|c|c|c|c|c|c|c|c|c|c|}
\hline SV & DF & YIELD & DA & DS & ASI & PLHT & EHT & PASP & EASP & STGR & TABLAST \\
\hline \multicolumn{12}{|l|}{ CDHS environment } \\
\hline ENV & 1 & 595549601.1 ** & $4.190 * *$ & $3.45 * *$ & 0.02 ** & 1021.33ns & $4365.28 * *$ & $9.20 * *$ & $69.69^{* *}$ & $32.77 * *$ & $2.45^{* *}$ \\
\hline SET & 5 & $90806981.5^{* *}$ & $42.08^{* *}$ & $28.27^{* *}$ & $4.18^{* *}$ & $3402.94 n s$ & $2542.63 * *$ & $10.94^{* *}$ & $14.09^{* *}$ & $1.30 \mathrm{~ns}$ & $0.11 \mathrm{~ns}$ \\
\hline $\operatorname{Rep}\left(\mathrm{ENV}^{*} \mathrm{SET}\right)$ & 10 & $3262635.4 \mathrm{~ns}$ & $4.83 \mathrm{~ns}$ & $5.55 \mathrm{~ns}$ & $0.66 \mathrm{~ns}$ & 1965.49ns & $33.84 \mathrm{~ns}$ & $1.36 \mathrm{~ns}$ & $0.86 \mathrm{~ns}$ & $0.70 \mathrm{~ns}$ & $0.08 \mathrm{~ns}$ \\
\hline Block(ENV*Rep) & 36 & $6681421.9^{* *}$ & $16.47^{* *}$ & $22.09^{* *}$ & $1.66^{*}$ & 3090.16ns & $165.32 * *$ & 3.89 ** & $2.95^{* *}$ & $3.32 * *$ & $0.12 * *$ \\
\hline HYBRID & 99 & 1419012 ** & $8.53 * *$ & $9.98 * *$ & $1.26 \mathrm{~ns}$ & 4279.06ns & $323.48^{* *}$ & $1.96 * *$ & $2.86^{* *}$ & $1.07^{*}$ & $0.12 * *$ \\
\hline $\mathrm{GCA}_{\mathrm{MALE}}(\mathrm{SET})$ & 18 & $1666352.2 \mathrm{~ns}$ & $9.92 * *$ & $12.88^{* *}$ & $1.14 \mathrm{~ns}$ & $5610.35 \mathrm{~ns}$ & $311.05^{* *}$ & $1.20 \mathrm{~ns}$ & $2.01 \mathrm{~ns}$ & $1.32 *$ & $0.14^{* *}$ \\
\hline GCA $_{\text {FEMALE }}(\mathrm{SET})$ & 18 & $6944283.3^{* *}$ & $10.65^{* *}$ & $13.13^{* *}$ & $1.24 \mathrm{~ns}$ & $5084.04 \mathrm{~ns}$ & $269.36^{* *}$ & $2.42 * *$ & $1.95 \mathrm{~ns}$ & $1.37^{*}$ & $0.08 \mathrm{~ns}$ \\
\hline SCA(SET) & 54 & $3790544.1^{*}$ & $4.20 *$ & $5.81 \mathrm{~ns}$ & $1.21 \mathrm{~ns}$ & $3610.24 \mathrm{~ns}$ & $118.18^{* *}$ & $0.99 \mathrm{~ns}$ & $2.14 \mathrm{~ns}$ & $1.01 \mathrm{~ns}$ & $0.14^{* *}$ \\
\hline ENV $^{*}$ HYBRID & 99 & $781347.6^{* *}$ & $4.74^{* *}$ & $6.38 * *$ & $1.47^{*}$ & $3898.23 n s$ & $64.11 \mathrm{~ns}$ & $1.86^{* *}$ & $2.58^{* *}$ & $1.16^{*}$ & $0.11^{* *}$ \\
\hline $\mathrm{ENV}^{*} \mathrm{GCA}_{\mathrm{MALE}}(\mathrm{SET})$ & 18 & $2723378.3 \mathrm{~ns}$ & $2.67 \mathrm{~ns}$ & $2.97 \mathrm{~ns}$ & $1.42 \mathrm{~ns}$ & $4486.43 n s$ & $79.26 \mathrm{~ns}$ & $1.43 \mathrm{~ns}$ & $4.36^{* *}$ & $1.13 \mathrm{~ns}$ & $0.14^{* *}$ \\
\hline $\mathrm{ENV}^{*} \mathrm{GCA}_{\text {FEMALE }}(\mathrm{SET})$ & 18 & $6455338.8^{* *}$ & $3.48 \mathrm{~ns}$ & $6.88^{*}$ & $1.57 \mathrm{~ns}$ & $4644.67 \mathrm{~ns}$ & $48.45 \mathrm{~ns}$ & $2.11 *$ & $3.36^{* *}$ & $1.38^{*}$ & $0.07 \mathrm{~ns}$ \\
\hline ENV*SCA(SET) & 54 & $4069373.8^{* *}$ & $5.54^{* *}$ & $8.02 * *$ & $1.33 \mathrm{~ns}$ & $3588.54 \mathrm{~ns}$ & $63.04 \mathrm{~ns}$ & $1.35 \mathrm{~ns}$ & $1.47 \mathrm{~ns}$ & $1.18^{*}$ & $0.10^{* *}$ \\
\hline Error & 143 & 2517929 & 2.95 & 4.19 & 1.06 & 3995.32 & 57.15 & 11.14 & 1.56 & 0.78 & 0.05 \\
\hline $\mathrm{H}^{2}$ & - & 0.37 & 0.54 & 0.50 & 0.27 & 0.39 & 0.74 & 0.41 & 0.51 & 0.26 & 0.31 \\
\hline \multicolumn{12}{|l|}{ Low-nitrogen environment } \\
\hline ENV & 1 & $2092131.3 *$ & $2218.83^{* *}$ & $1492.62 * *$ & $256.67 * *$ & $16102.05^{* *}$ & $2585.48^{* *}$ & $56.80 * *$ & $39.09 * *$ & 27.589 ** & - \\
\hline SET & 5 & $4087462.8^{* *}$ & $5.39 \mathrm{~ns}$ & $1.14 \mathrm{~ns}$ & $1.49 \mathrm{~ns}$ & $3901.85^{* *}$ & $1005.06^{* *}$ & $0.7^{* *}$ & $1.71^{* *}$ & $1.70 *$ & - \\
\hline $\mathrm{ENV}^{*} \mathrm{SET}$ & 5 & $2249671.8^{* *}$ & $8.88 \mathrm{~ns}$ & $9.11 \mathrm{~ns}$ & $0.47 \mathrm{~ns}$ & $214.05 \mathrm{~ns}$ & $176.55 n s$ & $0.15 \mathrm{~ns}$ & $0.39 \mathrm{~ns}$ & $1.02 \mathrm{~ns}$ & - \\
\hline $\operatorname{Rep}(E N V * S E T)$ & 10 & $458860 \mathrm{~ns}$ & $4.48 \mathrm{~ns}$ & $3.93 \mathrm{~ns}$ & $3.12 * *$ & $133.83 \mathrm{~ns}$ & $199.94 n s$ & $0.18 \mathrm{~ns}$ & $0.44 \mathrm{~ns}$ & $1.11 \mathrm{~ns}$ & - \\
\hline Block(ENV*Rep) & 36 & $5795924.1^{* *}$ & $12.51 * *$ & 27.29 ** & $2.27^{*}$ & $1222.36^{* *}$ & $510.66^{* *}$ & $2.80 * *$ & $3.63^{* *}$ & $3.07^{* *}$ & - \\
\hline HYBRID & 99 & $977907.6^{* *}$ & $5.54 * *$ & $7.12 * *$ & $0.51 \mathrm{~ns}$ & $481.69 * *$ & 178.59 ** & $2.26 \mathrm{~ns}$ & $1.92 * *$ & $1.92^{* *}$ & - \\
\hline $\mathrm{GCA}_{\mathrm{MALE}}(\mathrm{SET})$ & 18 & $1129415.8^{* *}$ & $7.73^{* *}$ & $12.78^{* *}$ & $1.28^{* *}$ & $545.15^{* *}$ & 156.09ns & $0.64^{*}$ & $0.46 \mathrm{~ns}$ & $0.8 \mathrm{~ns}$ & - \\
\hline $\mathrm{GCA}_{\text {FEMALE }}(\mathrm{SET})$ & 18 & 952771.1 * & $6.01 *$ & 10.60 ** & $0.72 \mathrm{~ns}$ & $452.67 * *$ & $171.41 \mathrm{~ns}$ & $0.31 *$ & $0.53^{* *}$ & $0.37^{*}$ & - \\
\hline SCA(SET) & 54 & $463614.4 \mathrm{~ns}$ & $3.93 \mathrm{~ns}$ & $5.05 \mathrm{~ns}$ & $0.88 \mathrm{~ns}$ & $100.34 \mathrm{~ns}$ & 101.36ns & $0.32 \mathrm{~ns}$ & $0.34 \mathrm{~ns}$ & $0.77 \mathrm{~ns}$ & - \\
\hline ENV*HYBRID & 99 & $977907.6^{* *}$ & $5.54 * *$ & $7.12 * *$ & $0.51 \mathrm{~ns}$ & $481.69^{* *}$ & $178.59 * *$ & $2.26^{* *}$ & $1.92 * *$ & $1.92 * *$ & - \\
\hline
\end{tabular}


Table 1. Cont.

\begin{tabular}{|c|c|c|c|c|c|c|c|c|c|c|c|}
\hline SV & DF & YIELD & DA & DS & ASI & PLHT & EHT & PASP & EASP & STGR & TABLAST \\
\hline $\mathrm{ENV}^{*} \mathrm{GCA}_{\mathrm{MALE}}(\mathrm{SET})$ & 18 & $684249 \mathrm{~ns}$ & $4.53 \mathrm{~ns}$ & $5.06 \mathrm{~ns}$ & $1.70 * *$ & $139.48 \mathrm{~ns}$ & $101.64 \mathrm{~ns}$ & $0.55 \mathrm{~ns}$ & $0.56 \mathrm{~ns}$ & $0.69 \mathrm{~ns}$ & - \\
\hline $\mathrm{ENV}^{*} \mathrm{GCA}_{\mathrm{FEMALE}}(\mathrm{SET})$ & 18 & $1254953.7^{* *}$ & $5.48 \mathrm{~ns}$ & $4.16 \mathrm{~ns}$ & $1.18 \mathrm{~ns}$ & $114.92 \mathrm{~ns}$ & $126.85 \mathrm{~ns}$ & $0.29 *$ & $0.63 * *$ & $0.71 \mathrm{~ns}$ & - \\
\hline $\mathrm{ENV}^{*} \mathrm{SCA}(\mathrm{SET})$ & 54 & 564756.6ns & $3.66 \mathrm{~ns}$ & $5.64 n s$ & $0.93 \mathrm{~ns}$ & $139.4 \mathrm{~ns}$ & $87.42 \mathrm{~ns}$ & $0.31 \mathrm{~ns}$ & $0.43 \mathrm{~ns}$ & $0.87 \mathrm{~ns}$ & - \\
\hline Error & 143 & 560355.6 & 3.49 & 4.76 & 0.76 & 151.37 & 109.3 & 0.39 & 0.54 & 0.73 & - \\
\hline $\mathrm{H}^{2}$ & - & 0.37 & 0.33 & 0.34 & 0.23 & 0.52 & 0.44 & 0.21 & 0.12 & 0.20 & - \\
\hline Repeatability & - & 0.71 & 0.66 & 0.68 & 0.58 & 0.83 & 0.69 & 0.63 & 0.56 & 0.58 & - \\
\hline
\end{tabular}

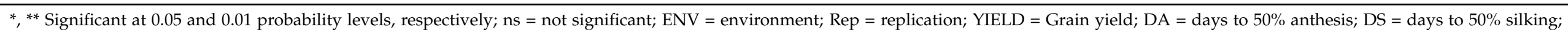
ÁSI = antheisi-silking interval; PLHT = plant height; EHT = ear height; PASP = plant aspect; EASP = ear aspect; STGR = stay green characteristic; TABLAST = tassel blast. 
Under the optimal environment conditions, significant $(p<0.01)$ differences in mean squares were observed for E, G and GEI for the measured traits, except the G and GEI mean squares for grain yield and ear rot (Table 2). In addition, significant differences $(p<0.01)$ were observed for GCAm, GCAf and SCA mean squares for measured traits except GCAf and SCA mean squares for grain yield and ear rot. Furthermore, significant mean squares for GCAm $\times$ E, GCAf $\times$ E and SCA $\times$ E were observed for measured traits except for grain yield. Broad-sense heritability estimates varied from $13 \%$ for ears per plant to $78 \%$ for plant height while grain yield recorded $\mathrm{H}^{2}$ of $41 \%$. Moderate to high repeatability estimates were recorded for measured traits. Across research environments, significant variations $(p<0.01)$ were observed among E, G and GEI mean squares for measured traits except the GEI for plant height (Table 2). Significant differences were observed for GCAm, GCAf, and SCA mean squares except the SCA mean squares for grain yield, days to $50 \%$ silking, plant height and ear rot. Significant mean squares for GCAm $\times$ E, GCAf $\times$ E and SCA $\times$ E were also observed for measured traits except for plant height and GCAm $\times$ E mean squares for plant aspect, plant height and ear rot as well as SCA $\times$ E mean squares for grain yield, plant aspect and plant height (Table 2).

\subsection{Proportionate Contributions of Genetic Variances under Low-Nitrogen, CDHS, Optimal and across Test Environments}

The percentage contributions of GCA and SCA variances were calculated as the proportion of the GCA components to the total genetic variance based on the sum of squares [35]. The percentage contribution of GCA (GCAm and GCAf) to the overall genotypic sum of squares for grain yield was higher under low-nitrogen $(60.1 \%)$ than under CDHS (43.1\%), optimal conditions (43.2\%) and across stress conditions (53.3\%). However, the percentage contribution of SCA sum of squares was highest under CDHS (56.9\%) and optimal conditions (56.7\%, Figure 1, Table 3). Under low-nitrogen environments, the contributions of GCA sum of squares (GCAm and GCAf) were predominantly higher than those of the SCA sum of squares for measured traits ranging from $(46.6 \%)$ for anthesissilking interval to $(76.7 \%)$ for plant height. Generally, the contribution of the GCA sum of squares was greater than the SCA sum of squares for grain yield and the other agronomic traits except for ASI. Under CDHS environment, the contribution of SCA sum of squares to the overall genotypic sum of squares among hybrids was greater than the GCA sum of squares for grain yield (56.9\%), ASI (60.4\%), plant height $(50.3 \%)$, ear aspect $(61.8 \%)$, ears per plant $(67.7 \%)$ and the stay green characteristic (52.9\%) (Figure 1 and Table 3$)$. Under optimal conditions, the contribution of the SCA sum of squares were greater than GCA sum of squares for grain yield, ASI, ear aspect and ears per plant. Additionally, the contribution of the GCA sum of squares ranged from 32.3\% for ears per plant to $62.1 \%$ for ear height. Across test environments, the contribution of GCA sum of squares was higher than the SCA sum of squares for most measured traits. The proportion of the GCA sum of squares relative to the total sum of squares of the hybrids varied from $38.5 \%$ for ASI to $77.1 \%$ for days to $50 \%$ silking while the contribution of the SCA sum of squares ranged from $22.8 \%$ for days to $50 \%$ silking to $61.5 \%$ for ASI across test environments. The GCA sum of squares accounted for $51 \%$ of the total sum of squares attributable to grain yield (Table 3 ). 


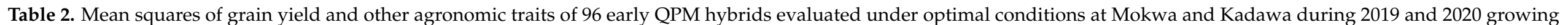
seasons and across test environments.

\begin{tabular}{|c|c|c|c|c|c|c|c|c|c|c|}
\hline SV & DF & YIELD & DA & DS & ASI & PLHT & EHT & PASP & EASP & EROT \\
\hline \multicolumn{11}{|l|}{ Optimal environments } \\
\hline ENV & 2 & $654194407^{* *}$ & $11058.25^{* *}$ & $12565.68^{* *}$ & $196.41^{* *}$ & $431852.40^{* *}$ & $110406.77^{* *}$ & $82.65^{* *}$ & $45.28^{* *}$ & $1053.99^{* *}$ \\
\hline SET & 5 & $19427073^{* *}$ & $9.54^{* *}$ & $6.97 \mathrm{~ns}$ & $2.62 * *$ & $9601.23 * *$ & $2308.62 * *$ & $10.21^{* *}$ & $11.46^{* *}$ & $1.36 \mathrm{~ns}$ \\
\hline $\operatorname{Rep}\left(\mathrm{ENV}^{*} \mathrm{SET}\right)$ & 15 & 2900486ns & $2.13 \mathrm{~ns}$ & $5.47 \mathrm{~ns}$ & $1.22 * *$ & $116.18 \mathrm{~ns}$ & $96.09 \mathrm{~ns}$ & $0.48 \mathrm{~ns}$ & $0.78 \mathrm{~ns}$ & $1.80 \mathrm{~ns}$ \\
\hline Block(ENV*Rep) & 54 & 6629211ns & $6.56^{* *}$ & $6.17^{* *}$ & $0.73 \mathrm{~ns}$ & $480.07^{* *}$ & 324.82 ** & $0.55^{* *}$ & $1.13^{* *}$ & $4.62 * *$ \\
\hline HYBRID & 99 & 5711483ns & 12.52 ** & $10.35^{* *}$ & $1.10^{* *}$ & $940.42 * *$ & $312.43^{* *}$ & $1.47^{* *}$ & $1.69^{* *}$ & $2.32 \mathrm{~ns}$ \\
\hline $\mathrm{GCA}_{\mathrm{MALE}}(\mathrm{SET})$ & 18 & $8462986^{* *}$ & 10.74 ** & $9.98 * *$ & $0.45 \mathrm{~ns}$ & $632.78 * *$ & $294.88^{* *}$ & $0.90 * *$ & $1.09^{* *}$ & $1.84 \mathrm{~ns}$ \\
\hline $\mathrm{GCA}_{\text {FEMALE }}(\mathrm{SET})$ & 18 & $2666167 \mathrm{~ns}$ & $22.88^{* *}$ & $18.30^{* *}$ & $1.00 \mathrm{~ns}$ & $823.93 * *$ & $322.12 * *$ & $1.43^{* *}$ & $1.08^{* *}$ & $2.94 \mathrm{~ns}$ \\
\hline SCA(SET) & 54 & $4859033 \mathrm{~ns}$ & $7.10^{* *}$ & $5.07^{* *}$ & $1.04 * *$ & $162.70 * *$ & $130.02 * *$ & $0.65 * *$ & $0.87^{* *}$ & $2.26 \mathrm{~ns}$ \\
\hline ENV*HYBRID & 198 & 5182385ns & $6.97^{* *}$ & $7.62 * *$ & $1.00 * *$ & $190.53^{* *}$ & $146.94^{* *}$ & $0.57^{* *}$ & $0.71 *$ & $2.31 \mathrm{~ns}$ \\
\hline $\mathrm{ENV}^{*} \mathrm{GCA}_{\mathrm{MALE}}(\mathrm{SET})$ & 36 & $6852042 n s$ & $6.31^{* *}$ & $7.42 * *$ & $1.18^{* *}$ & $304.61^{* *}$ & $180.37^{* *}$ & $0.39 \mathrm{~ns}$ & $0.79 \mathrm{~ns}$ & $2.38 \mathrm{~ns}$ \\
\hline $\mathrm{ENV}^{*} \mathrm{GCA}_{\mathrm{FEMALE}}(\mathrm{SET})$ & 36 & 5273256ns & $6.77 * *$ & $9.46^{* *}$ & 0.96 ** & $202.93 * *$ & $211.50 * *$ & $0.62 * *$ & $0.58 \mathrm{~ns}$ & $2.95^{* *}$ \\
\hline ENV*SCA(SET) & 108 & $4299183 \mathrm{~ns}$ & $5.20^{* *}$ & $5.33 * *$ & $0.99 * *$ & $148.51 * *$ & $116.89^{* *}$ & $0.57^{* *}$ & $0.71 \mathrm{~ns}$ & $2.19 \mathrm{~ns}$ \\
\hline Error & 215 & 4941851 & 3.57 & 3.54 & 0.62 & 100.2 & 88.35 & 0.4 & 0.57 & 1.97 \\
\hline $\mathrm{H}^{2}$ & - & 0.41 & 0.48 & 0.53 & 0.38 & 0.78 & 0.6 & 0.58 & 0.51 & - \\
\hline \multicolumn{11}{|l|}{ Across environments } \\
\hline ENV & 6 & $499379987^{* *}$ & $13849.13^{* *}$ & $15593.72 * *$ & $123.97^{* *}$ & $154513.34^{* *}$ & $45040.16^{* *}$ & $46.41^{* *}$ & $54.38^{* *}$ & $557.78^{* *}$ \\
\hline SET & 5 & $25520360 * *$ & 34.39 ** & $12.66^{* *}$ & $5.60 * *$ & $14753.19^{* *}$ & $5416.08^{* *}$ & $17.53^{* *}$ & $22.77^{* *}$ & $2.59 \mathrm{~ns}$ \\
\hline ENV*SET & 30 & $3762534^{*}$ & $13.86^{* *}$ & $15.39^{* *}$ & $1.52 * *$ & 942.61ns & $171.52 * *$ & $2.28^{* *}$ & $1.45^{*}$ & $1.82 \mathrm{~ns}$ \\
\hline $\operatorname{Rep}\left(\mathrm{ENV}^{*} \mathrm{SET}\right)$ & 35 & $1608595 \mathrm{~ns}$ & $3.58 \mathrm{~ns}$ & $5.06 \mathrm{~ns}$ & $1.59 * *$ & 649.6ns & $107.98 \mathrm{~ns}$ & $0.65 \mathrm{~ns}$ & $0.71 \mathrm{~ns}$ & $1.42 \mathrm{~ns}$ \\
\hline Block(ENV*Rep) & 126 & $4851705^{* *}$ & $11.09^{* *}$ & $16.75^{* *}$ & $1.41^{* *}$ & 1437.89 & $332.34^{* *}$ & $2.15^{* *}$ & $2.37^{* *}$ & $5.77^{* *}$ \\
\hline HYBRID & 99 & $4126473^{* *}$ & $15.01^{* *}$ & 15.52 ** & $1.40^{* *}$ & $3033.39^{* *}$ & $605.93^{* *}$ & $2.41^{* *}$ & $2.74^{* *}$ & $2.94^{* *}$ \\
\hline $\mathrm{GCA}_{\mathrm{MALE}}(\mathrm{SET})$ & 18 & $4424226^{* *}$ & $19.75^{* *}$ & $24.77^{* *}$ & $1.52 *$ & 3653.58 ** & $532.65^{* *}$ & $1.21^{* *}$ & $1.16 \mathrm{~ns}$ & $4.11^{* *}$ \\
\hline
\end{tabular}


Table 2. Cont.

\begin{tabular}{|c|c|c|c|c|c|c|c|c|c|c|}
\hline SV & DF & YIELD & DA & DS & ASI & PLHT & EHT & PASP & EASP & EROT \\
\hline GCA $_{\text {FEMALE }}(\mathrm{SET})$ & 18 & $2103577^{*}$ & $24.74^{* *}$ & $25.50 * *$ & $0.69 \mathrm{~ns}$ & $3564.40^{* *}$ & $586.29 * *$ & $2.50 * *$ & $1.57^{*}$ & $3.90^{* *}$ \\
\hline SCA(SET) & 54 & 2094763ns & $5.53 * *$ & $4.97 \mathrm{~ns}$ & $1.18^{*}$ & $1368.91 \mathrm{~ns}$ & $149.13^{* *}$ & $0.97^{* *}$ & $1.26^{*}$ & $1.72 \mathrm{~ns}$ \\
\hline ENV*HYBRID & 594 & $2629285^{* *}$ & $5.86^{* *}$ & $6.56^{* *}$ & $1.14 * *$ & $1173.7 \mathrm{~ns}$ & $111.95^{* *}$ & 0.81 ** & $1.20 * *$ & $2.31 * *$ \\
\hline $\mathrm{ENV}^{*} \mathrm{GCA}_{\text {FEMALE }}(\mathrm{SET})$ & 108 & $2453356^{* *}$ & $6.25 * *$ & $7.74 * *$ & $1.13^{* *}$ & 1357.17ns & $130.50 * *$ & $0.86^{*}$ & $1.21 * *$ & $2.84^{* *}$ \\
\hline ENV*SCA(SET) & 323 & 2295330ns & $4.93 * *$ & $5.98^{* *}$ & $1.05^{* *}$ & $1085.28 \mathrm{~ns}$ & $97.5 \mathrm{~ns}$ & $0.64 n s$ & $0.94 \mathrm{~ns}$ & $2.30 *$ \\
\hline Error & 501 & 2474083 & 3.37 & 4.08 & 0.8 & 1226.59 & 85.42 & 0.61 & 0.85 & 1.9 \\
\hline
\end{tabular}

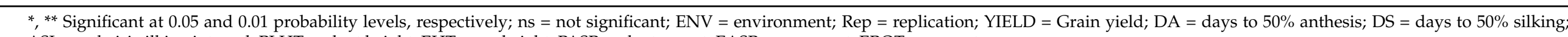
ÁSI = antheisi-silking interval; PLHT = plant height; EHT = ear height; PASP = plant aspect; EASP = ear aspect; EROT = ears rot.

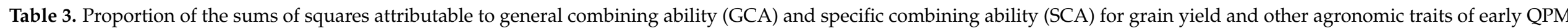
inbred lines under low-nitrogen, CDHS, optimal and across test environments.

\begin{tabular}{|c|c|c|c|c|c|c|c|c|c|c|c|c|}
\hline \multirow[t]{3}{*}{ TRAITS } & \multirow{2}{*}{\multicolumn{2}{|c|}{$\begin{array}{c}\begin{array}{c}\text { Low- } \\
\text { Nitrogen }\end{array} \\
\text { GCA } \\
\end{array}$}} & \multirow{3}{*}{ SCA } & \multicolumn{3}{|c|}{ CDHS } & \multicolumn{2}{|c|}{$\begin{array}{c}\text { Optimal } \\
\text { Conditions }\end{array}$} & \multicolumn{3}{|c|}{$\begin{array}{c}\text { Across Test } \\
\text { Environments }\end{array}$} & \multirow{3}{*}{ SCA } \\
\hline & & & & GCA & & SCA & GCA & & SCA & GCA & & \\
\hline & Male & Female & & Male & Female & & Male & Female & & Male & Female & \\
\hline Grain yield $\left(\mathrm{kg} \mathrm{ha}^{-1}\right)$ & 32.5 & 27.5 & 39.9 & 8.3 & 34.8 & 56.9 & 32.9 & 10.4 & 56.7 & 34.5 & 16.4 & 49.0 \\
\hline Days to $50 \%$ anthesis & 32.6 & 25.0 & 42.4 & 29.9 & 32.1 & 38.0 & 19.6 & 41.7 & 38.8 & 32.3 & 40.5 & 27.2 \\
\hline Days to $50 \%$ silking & 33.7 & 27.1 & 39.2 & 29.6 & 30.2 & 40.1 & 22.9 & 42.1 & 35.0 & 38.0 & 39.1 & 22.9 \\
\hline Anthesis-silking interval & 31.6 & 15.0 & 53.4 & 19.0 & 20.6 & 60.4 & 9.8 & 22.0 & 68.2 & 26.5 & 12.0 & 61.5 \\
\hline Plant height & 41.2 & 35.6 & 23.2 & 26.1 & 23.6 & 50.3 & 32.5 & 42.4 & 25.1 & 32.3 & 31.5 & 36.3 \\
\hline$>$ Ear height & 24.9 & 27.1 & 48.0 & 33.3 & 28.8 & 37.9 & 29.3 & 32.0 & 38.7 & 34.0 & 37.4 & 28.6 \\
\hline Plant aspect & 30.1 & 26.8 & 43.1 & 18.2 & 36.8 & 45.0 & 21.0 & 33.5 & 45.5 & 18.4 & 37.8 & 43.8 \\
\hline Ear aspect & 22.0 & 36.2 & 41.8 & 19.4 & 18.8 & 61.9 & 22.9 & 22.6 & 54.5 & 17.8 & 24.1 & 58.1 \\
\hline Ears per plant & 28.3 & 25.8 & 45.9 & 13.9 & 18.4 & 67.7 & 21.8 & 25.8 & 52.4 & 20.1 & 30.2 & 49.7 \\
\hline Stay-green characteristics & 23.0 & 27.3 & 49.6 & 23.2 & 23.9 & 52.9 & - & - & - & - & - & - \\
\hline Tassel blast & - & - & - & 21.8 & 12.1 & 66.1 & - & - & - & - & - & - \\
\hline
\end{tabular}




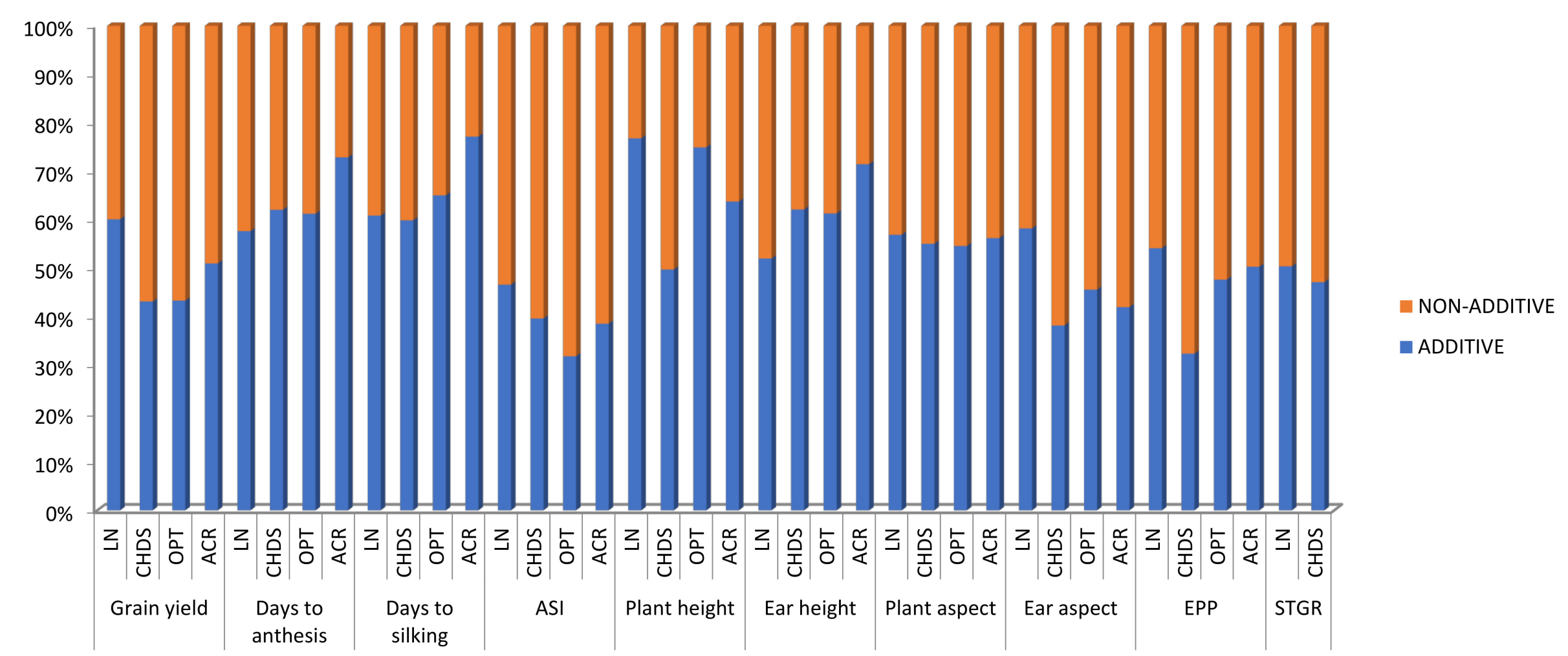

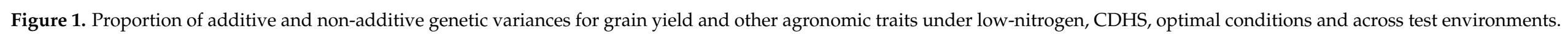




\subsection{Estimates of General Combining Ability Effects of the 24 QPM Inbred Lines}

Under low nitrogen environment conditions, the GCAm effects for grain yield ranged from -318.88 for TZEQI 165 to 567.43 for TZEQI 158 while the GCAf effects ranged from -612.63 for TZEQI 240 to 961.61 for TZEQI 210 (Table 4). Only TZEQI 6 had significant and positive GCAm and GCAf effects for grain yield. Inbreds TZEQI 106, TZEQI 113, TZEQI 158, TZEQI 188, and TZEQI 6 had significant and positive GCAm effects for grain yield while TZEQI 210 and TZEQI 6 had significant and positive GCAf effects for grain yield. Also, only TZEQI 106 recorded significant and negative GCAm and GCAf effects for the stay green characteristic. TZEQI 130, TZEQI 140, TZEQI 216 and TZEQI 6 had significant and negative GCAm effects for the stay green characteristic while TZEQI 210 had significant and negative GCAf effects for the stay green characteristic. Under CDHS conditions, the GCAm effects for grain yield varied from -633 for TZEQI 219 to 503 for TZEQI 216. No significant GCAf effects were recorded for any of the inbred lines, however TZEQI 113 and TZEQI 216 recorded significant and positive GCAm effects for grain yield. Inbred lines TZEQI 113, TZEQI 130, TZEQI 171 and TZEQI 188 had significant and negative GCAm effects for ASI while TZEQI 171, TZEQI 210, TZEQI 241 and TZEQI 6 recorded significant and negative GCAf effects for ASI. Of the 24 parental lines, only TZEQI 219 had significant and positive GCAm effects for grain yield under optimal environments (Table 4). Across test environments, GCAm effects for grain yield varied from -388 for TZEQI 241 to 685 for TZEQI 219 while the GCAf effects varied from -530 for TZEQI 240 to 452 for TZEQI 210. Significant and positive GCAm effects were recorded for TZEQI 219 and TZEQI 6 while significant and positive GCAf effects were detected for TZEQI 210 and TZEQI 241.

\subsection{Heterotic Grouping of Inbred Lines Based on General Combining Ability of Multiple Traits} (HGCAMT) Method

Across test environments, the dendrogram constructed using the HGCAMT method revealed four groups when $40 \%$ of the variation was explained $\left(\mathrm{r}^{2}=0.4\right)$ among the parental lines (Figure 2). Eleven inbred lines (TZEQI 106, TZEQI 210, TZEQI 241, TZEQI 123, TZEQI 171, TZEQI 162, TZEQI 130, TZEQI 143, TZEQI 175, TZEQI 176, TZEQI 216) were placed in heterotic group I while TZEQI 132, TZEQI 188, TZEQI 219, TZEQI 159, and TZEQI 240 constituted heterotic group II. Inbreds TZEQI 113, TZEQI 158, TZEQI 6 and TZEQI 140 were placed in heterotic group III with the remaining four inbred lines TZEQI 122, TZEQI 246, TZEQI 228 and TZEQI 165 classified into heterotic group IV. Inbred lines TZEQI 113, TZEQI 158, and TZEQI 6 with significant and positive GCA effects for grain yield were placed in the same heterotic group III. Interestingly, inbred lines TZEQI 106 and TZEQI 210 with significant and positive GCA effects for grain yield under low-nitrogen environments were placed in heterotic group I.

\subsection{Identification of Inbred and Single-Cross Hybrid Testers}

Based on the criteria proposed by Pswarayi and Vivek [36], inbred TZEQI 6 which had high per se grain yield as well as significant and positive GCA effects for grain yield was identified as an inbred tester under low-nitrogen conditions. Hybrid TZEQI $113 \times$ TZEQI 6 was also identified as a single-cross tester. 
Table 4. GCA effects of the 24 early QPM inbred lines for grain yield and other agronomic traits evaluated under CDHS, low soil nitrogen, optimal and across test environments.

\begin{tabular}{|c|c|c|c|c|c|c|c|c|c|c|c|c|c|c|}
\hline \multirow[b]{3}{*}{ INBREDS } & \multicolumn{4}{|c|}{ Low Soil Nitrogen } & \multicolumn{6}{|c|}{ Combined Drought and Heat Stress Conditions } & \multirow{2}{*}{\multicolumn{2}{|c|}{$\begin{array}{c}\text { Optimal Conditions } \\
\text { Grain Yield }\end{array}$}} & \multirow{2}{*}{\multicolumn{2}{|c|}{$\begin{array}{c}\begin{array}{c}\text { Across Test } \\
\text { Environments }\end{array} \\
\text { Grain Yield }\end{array}$}} \\
\hline & \multicolumn{2}{|c|}{ Grain Yield } & \multicolumn{2}{|c|}{$\begin{array}{c}\text { Stay Green } \\
\text { Characteristic }\end{array}$} & \multicolumn{2}{|c|}{ Grain Yield } & \multicolumn{2}{|c|}{ ASI } & \multicolumn{2}{|c|}{$\begin{array}{c}\text { Stay Green } \\
\text { Characteristic }\end{array}$} & & & & \\
\hline & GCAm & GCAf & GCAm & GCAf & GCAm & GCAf & GCAm & GCAf & GCAm & GCAf & GCAm & GCAf & GCAm & GCAf \\
\hline TZEQI 106 & $310.57^{*}$ & 174.91 & $-0.45^{* *}$ & $-0.40 *$ & -53.52 & 63.06 & 0.1 & 0.27 & 0.21 & $0.32 *$ & -179.3 & -210.65 & 3.22 & 372.64 \\
\hline TZEQI 113 & $415.18^{* *}$ & -10.83 & -0.1 & 0.13 & $502.79 *$ & -265.53 & $-0.38^{* *}$ & -0.05 & -0.11 & $-0.31 *$ & 266.62 & -49.47 & 372.64 & -96.19 \\
\hline TZEQI 122 & -216.37 & 163.56 & 0.3 & 0.29 & $-521.41^{*}$ & -159.89 & 0.21 & -0.13 & 0.03 & -0.11 & 200.59 & 12.34 & -116.3 & 26.39 \\
\hline TZEQI 123 & $-509.38^{* *}$ & -327.64 & 0.26 & -0.02 & 72.14 & 362.37 & 0.07 & -0.09 & -0.13 & 0.1 & -287.91 & 247.78 & -259.56 & 107.96 \\
\hline TZEQI 132 & -91.59 & $-486.44^{*}$ & 0.26 & 0.03 & 16.35 & 75.92 & 0.11 & 0.2 & 0.07 & $-0.34^{*}$ & 192.46 & 189.82 & 3.88 & -27.77 \\
\hline TZEQI 140 & 208.01 & 298.45 & $-0.45^{* *}$ & 0.11 & -126.57 & 197.95 & 0 & 0.14 & $-0.44^{* *}$ & 0.43 * & 143.61 & 9.55 & 111.06 & 138.82 \\
\hline TZEQI 143 & $-292.25^{*}$ & 154.82 & $0.51^{* *}$ & -0.15 & -22.95 & -369.89 & 0.35 * & -0.13 & $0.27^{*}$ & -0.13 & -221.52 & -70.39 & -167.84 & -70.42 \\
\hline TZEQI 158 & $567.43^{* *}$ & 353.41 & -0.11 & -0.21 & 242.39 & 17.36 & 0 & 0.01 & $-0.39^{* *}$ & -0.04 & 25.9 & -81.61 & 222.11 & 57.76 \\
\hline TZEQI 159 & -94.48 & -260.67 & 0.15 & -0.07 & -163.59 & -390.22 & -0.04 & 0.25 & $0.57^{* *}$ & 0.43 * & -259.52 & -267.4 & -109.65 & -281.54 \\
\hline TZEQI 162 & -154.07 & -160 & 0.07 & 0 & -19.1 & 233.1 & -0.25 & -0.13 & -0.05 & -0.14 & -170.91 & -83.24 & -151.5 & -50.1 \\
\hline TZEQI 165 & $-318.88^{*}$ & 67.26 & -0.12 & 0.28 & -59.7 & 139.75 & $0.29 *$ & -0.13 & -0.13 & -0.25 & 404.53 & 432.25 & 39.05 & 273.87 \\
\hline TZEQI 171 & -85.12 & 179.5 & 0.16 & 0.08 & -52.95 & -64.34 & $-0.34^{*}$ & $-0.57^{* *}$ & -0.12 & $-0.30 *$ & -59 & -443.47 & -57.96 & -79.77 \\
\hline TZEQI 176 & -85.69 & -254.56 & -0.19 & 0.13 & -60.98 & 206.04 & $0.28 *$ & $0.48^{* *}$ & -0.12 & $0.35 *$ & 87.82 & 29.46 & -16.28 & -17.64 \\
\hline TZEQI 188 & $372.49^{*}$ & 120.83 & 0.01 & -0.15 & -136 & -408.08 & $-0.25^{*}$ & 0.23 & $0.42^{* *}$ & 0.05 & 317.17 & 159.3 & 201.2 & -41.28 \\
\hline TZEQI 210 & 208.06 & $961.61^{* *}$ & -0.01 & $-0.45^{*}$ & 81.41 & 256.99 & -0.08 & $-0.27^{*}$ & -0.25 & 0.50 ** & -972.07 & 267.01 & -382.49 & $452.05^{*}$ \\
\hline TZEQI 216 & $-292.18^{*}$ & $-575.11^{*}$ & $-0.30 *$ & 0.07 & $503.03 *$ & 356.13 & -0.05 & -0.09 & 0.07 & -0.12 & -391.84 & -61.44 & -166.81 & -104.27 \\
\hline TZEQI 219 & -144.21 & -101.23 & 0.02 & -0.07 & $-633.01 * *$ & -470.69 & 0.12 & $0.29 *$ & 0.03 & $-0.52^{* *}$ & $1868.26^{* *}$ & 148.87 & $685.06^{* *}$ & -74.52 \\
\hline TZEQI 228 & 228.33 & -285.26 & $0.28^{*}$ & $0.45^{*}$ & 48.56 & -142.44 & 0.01 & 0.07 & 0.15 & 0.14 & -504.36 & -354.45 & -135.76 & -273.26 \\
\hline TZEQI 240 & 77.6 & $-612.63 *$ & $0.32 *$ & 0.22 & -185.6 & -233.38 & 0.01 & 0.27 & -0.13 & -0.02 & 167.76 & -716.16 & 42.49 & -530.95 \\
\hline TZEQI 241 & $-312.11 *$ & 60.19 & 0.13 & 0.04 & -372.45 & 104.62 & -0.12 & $-0.33 *$ & $-0.28 *$ & 0.12 & -409.54 & 763.95 & -388.39 & $410.10^{*}$ \\
\hline TZEQI 246 & -252.43 & -121.31 & 0.16 & 0.02 & 230.7 & -22.51 & 0.15 & 0.38 * & -0.18 & 0.29 & -247.34 & -225.03 & -115.52 & -136.02 \\
\hline TZEQI 6 & $486.95^{* *}$ & $673.75^{* *}$ & $-0.61^{* *}$ & -0.28 & 327.35 & 151.28 & -0.04 & -0.32 * & $0.59^{* *}$ & -0.39 * & 489.12 & 177.24 & $461.42 *$ & 256.87 \\
\hline S.E & 135.26 & 225.71 & 0.14 & 0.17 & 206.28 & 317.59 & 0.15 & 0.16 & 0.13 & 0.15 & 427.46 & 459.27 & 230.05 & 195.79 \\
\hline
\end{tabular}




\section{ENTRY}

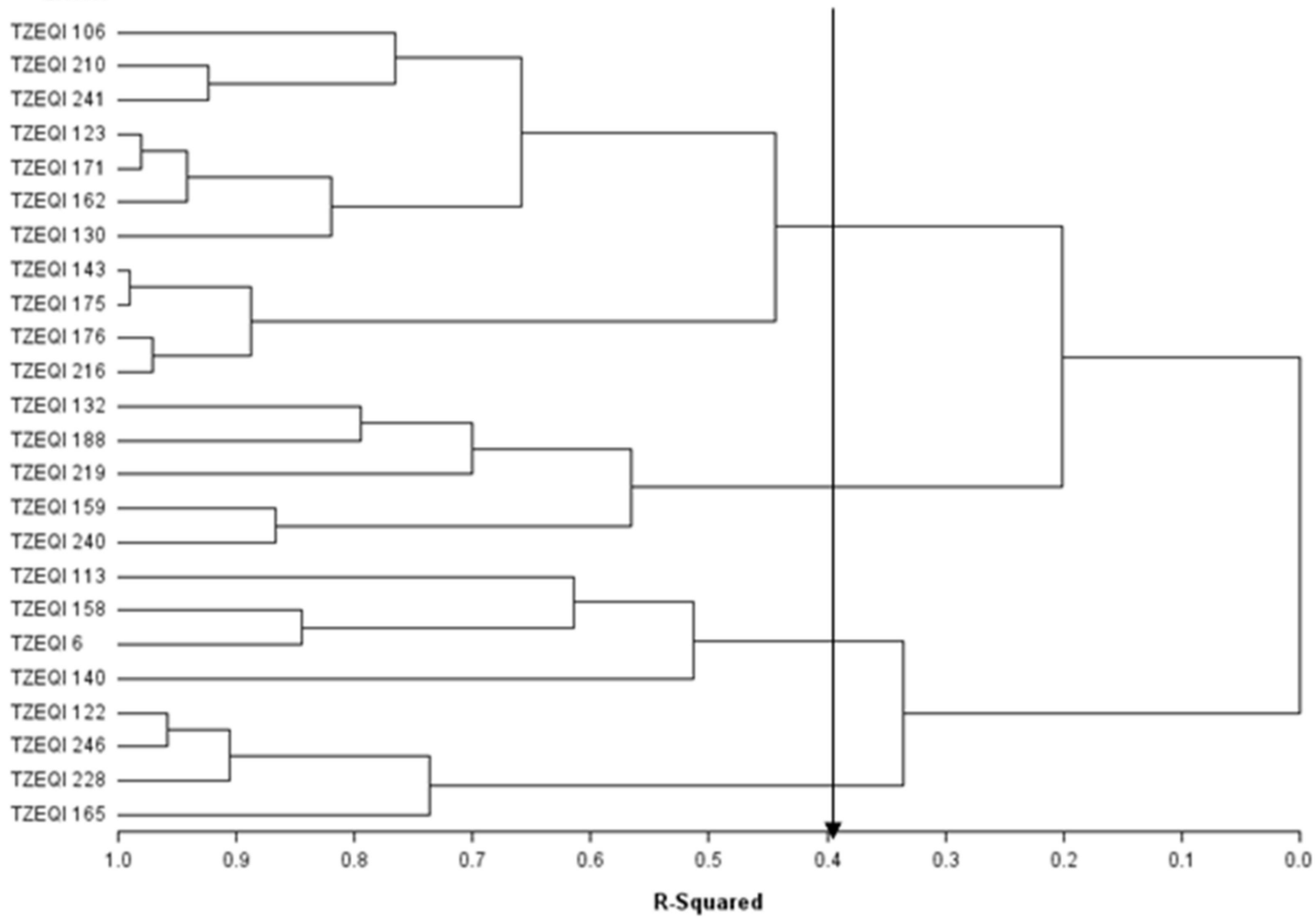

Figure 2. Heterotic grouping of the 24 early white QPM inbred lines.

\subsection{Grain Yield in Contrasting Environments}

Under CDHS environments, grain yield ranged from $342 \mathrm{~kg} \mathrm{ha}^{-1}$ for TZEQI 143 $\times$ TZEQI 122 to $3885 \mathrm{~kg} \mathrm{ha}^{-1}$ for hybrid check TZEQI $39 \times$ TZEQI 44 with a mean of $1578 \mathrm{~kg} \mathrm{ha}^{-1}$. The hybrid check out-yielded the highest yielding QPM hybrid by 7\% (Table 5). Grain yield of the QPM hybrids under low-nitrogen environment, ranged from $1511 \mathrm{~kg} \mathrm{ha}^{-1}$ for TZEQI $132 \times$ TZEQI 122 to $5388 \mathrm{~kg} \mathrm{ha}^{-1}$ for TZEQI $210 \times$ TZEQI 188 with a mean of $3057 \mathrm{~kg} \mathrm{ha}^{-1}$. TZEQI $210 \times$ TZEQI 188 out-yielded the highest yielding hybrid check by $18 \%$. Under optimal conditions, grain yield ranged from $3807 \mathrm{~kg} \mathrm{ha}^{-1}$ for TZEQI $241 \times$ TZEQI 216 to $6692 \mathrm{~kg} \mathrm{ha}^{-1}$ for TZEQI $210 \times$ TZEQI 188 with a mean of $5164 \mathrm{~kg} \mathrm{ha}^{-1}$. Comparison of the grain yield of the QPM hybrids under CDHS environment to that of optimal environments showed a wide reduction ingrain yield (5-93\%) with a mean of 67\% while grain yield reduction under low-nitrogen environments revealed a yield reduction range of $8 \%$ to $74 \%$ with a mean of $44.9 \%$. Overall, the CDHS and low-nitrogen tolerant QPM hybrids recorded lower reductions in grain yield than the susceptible QPM hybrids (Table 5).

\subsection{Grain Yield Stability of Hybrids across Test Environments}

The observed significant differences for genotype by environment interactions for grain yield under CDHS, low-nitrogen and across test environments justified the need to investigate the grain yield stability of the early QPM hybrids across the test environments using the genotype plus genotype by environment (GGE) biplot procedure. The GGE biplot analysis revealed that the first and second principal component axes explained $65.5 \%$ of the total variation in grain yield of the QPM hybrids (Figures 3 and 4). The "which-wonwhere" view of the GGE biplot procedure was used to identify hybrids adapted to specific 
environments. In the polygon view, the vertex entries represented the highest yielding hybrids in the environments that fell within the sector. The distance between the hybrids and the biplot origin measured the differences in the performance of the hybrids and how they differed from the mean yields of other hybrids. Therefore, the vertex hybrids in each sector were more responsive to the environments than those that fell within the polygon or located close to the biplot origin. There were eight vectors with hybrids $1,2,6,10,17$, 20, 24, and 25 as the vertex hybrids (Figure 3). Two environments E2 and E6 fell within the sector where hybrids TZEQI $241 \times$ TZEQI 216 and TZEQI $6 \times$ TZEQI 55 (check) were the vertex hybrids. Similarly, environments E1 and E3 fell within the sector where hybrids TZEQI $6 \times$ TZEQI 210 and TZEQI $39 \times$ TZEQI 44 (check) were the vertex hybrids and were therefore considered the highest yielding in those environments. Environments E4, E5 and E7 had no vertex hybrids and therefore no outstanding hybrids were identified in those environments. Entries 1, 2, 6, and 10 were vertex hybrids but they were not identified with any environments. Entries 13 and 15 (TZEQI $171 \times$ TZEQI 158 and TZEQI $210 \times$ TZEQI 171) were the least responsive hybrids to environmental variability due to their closeness to the biplot origin.

Table 5. Grain yield performance of selected QPM hybrids across the stress environments.

\begin{tabular}{|c|c|c|c|c|c|c|c|}
\hline \multirow[b]{2}{*}{ Hybrids } & \multicolumn{4}{|c|}{ Grain Yield } & \multicolumn{2}{|c|}{ Yield Reduction (\%) } & \multirow[b]{2}{*}{ MI } \\
\hline & CDHS & Low-Nitrogen & Optimal & Across & Low-Nitrogen & CDHS & \\
\hline TZEQI $6 \times$ TZEQI 228 & 2134 & 3826 & 6386 & 4031 & 40.1 & 66.6 & 11.1 \\
\hline TZEQI $210 \times$ TZEQI 188 & 1954 & 5388 & 6692 & 4582 & 19.5 & 70.8 & 11.0 \\
\hline TZEQI 6 × TZEQI 55(check) & 2104 & 3832 & 6622 & 4716 & 42.1 & 68.2 & 9.4 \\
\hline TZEQI $113 \times$ TZEQI 6 & 1613 & 4451 & 5643 & 3760 & 21.1 & 71.4 & 8.5 \\
\hline TZEQI $6 \times$ TZEQI 210 & 2471 & 4483 & 6671 & 3613 & 32.8 & 63.0 & 8.4 \\
\hline TZEQI $241 \times$ TZEQI 228 & 2699 & 4700 & 5145 & 3815 & 8.6 & 47.5 & 7.9 \\
\hline TZEQI $246 \times$ TZEQI 210 & 2146 & 4255 & 5055 & 3720 & 15.8 & 57.6 & 7.1 \\
\hline TZEQI $241 \times$ TZEQI 216 & 3604 & 3066 & 3807 & 3566 & 19.5 & 5.3 & 6.8 \\
\hline TZEQI 6 × TZEQI 219 & 1350 & 4314 & 6359 & 4607 & 32.2 & 78.8 & 6.6 \\
\hline TZEQI 39 × TZEQI 44(check) & 3885 & 3877 & 6639 & 4627 & 41.6 & 41.5 & 5.6 \\
\hline TZEQI $39 \times$ TZEQI 14(check) & 2303 & 4435 & 5543 & 3854 & 20.0 & 58.5 & 5.6 \\
\hline TZEQI $171 \times$ TZEQI 158 & 2206 & 3878 & 4784 & 3288 & 19.0 & 53.9 & 5.5 \\
\hline TZEQI $106 \times$ TZEQI 6 & 1620 & 3307 & 3943 & 2858 & 16.1 & 58.9 & 4.9 \\
\hline TZEQI $210 \times$ TZEQI 171 & 2344 & 3390 & 6506 & 3871 & 47.9 & 64.0 & 4.5 \\
\hline TZEQI $140 \times$ TZEQI 113 & 2139 & 4227 & 5098 & 3384 & 17.1 & 58.0 & 4.2 \\
\hline TZEQI $113 \times$ TZEQI 240 & 632 & 2475 & 4877 & 2626 & 49.3 & 87.0 & -5.7 \\
\hline TZEQI $140 \times$ TZEQI 106 & 664 & 2628 & 5161 & 2760 & 49.1 & 87.1 & -6.4 \\
\hline TZEQI $165 \times$ TZEQI 132 & 1804 & 2698 & 5391 & 2827 & 49.9 & 66.5 & -6.4 \\
\hline TZEQI $130 \times$ TZEQI 123 & 1418 & 2242 & 4780 & 2368 & 53.1 & 70.3 & -6.6 \\
\hline TZEQI $132 \times$ TZEQI 113 & 1236 & 2180 & 4990 & 2584 & 56.3 & 75.2 & -7.0 \\
\hline TZEQI $175 \times$ TZEQI 159 & 1124 & 1930 & 4916 & 2491 & 60.8 & 77.1 & -7.2 \\
\hline TZEQI $132 \times$ TZEQI 122 & 703 & 1511 & 5741 & 2548 & 73.7 & 87.8 & -7.6 \\
\hline TZEQI $143 \times$ TZEQI 122 & 342 & 2759 & 5037 & 2449 & 45.2 & 93.2 & -7.7 \\
\hline TZEQI $159 \times$ TZEQI 143 & 1045 & 2201 & 4883 & 2550 & 54.9 & 78.6 & -9.9 \\
\hline TZEQI $159 \times$ TZEQI 132 & 394 & 2003 & 4903 & 2368 & 59.1 & 92.0 & -12.8 \\
\hline Mean & 1578 & 3057 & 5164 & 3158 & 44.9 & 67.0 & \\
\hline S.E & 67 & 72 & 76 & 62 & & & \\
\hline
\end{tabular}




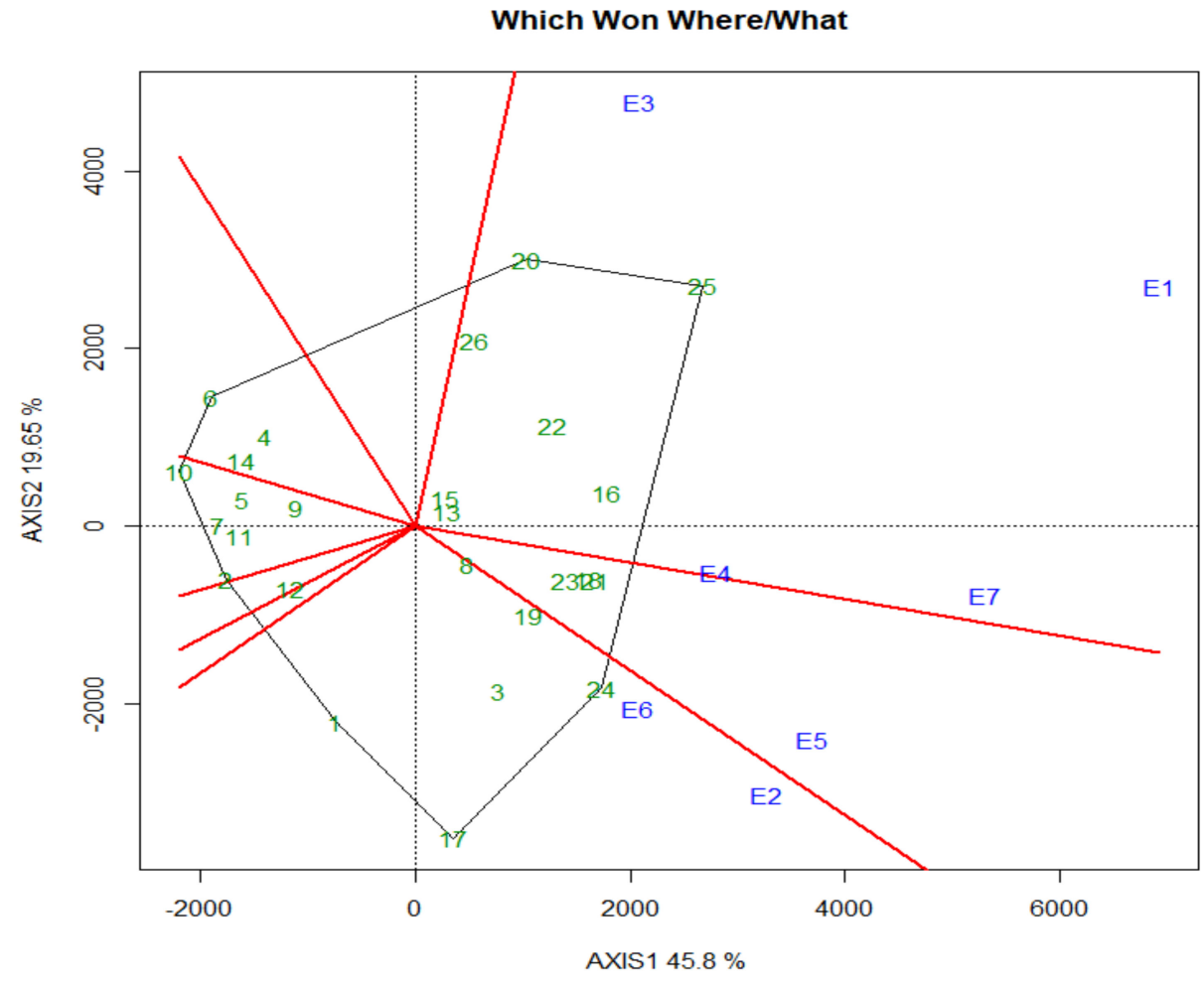

\begin{tabular}{|l|l|}
\hline Entry & Hybrids \\
\hline 1 & TZEQI $106 \times$ TZEQI 6 \\
\hline 2 & TZEQI $113 \times$ TZEQI 240 \\
\hline 3 & TZEQI $113 \times$ TZEQI 6 \\
\hline 4 & TZEQI $130 \times$ TZEQI 123 \\
\hline 5 & TZEQI $132 \times$ TZEQI 113 \\
\hline 6 & TZEQI $132 \times$ TZEQI 122 \\
\hline 7 & TZEQI $140 \times$ TZEQI 106 \\
\hline 8 & TZEQI $140 \times$ TZEQI 113 \\
\hline 9 & TZEQI $143 \times$ TZEQI 122 \\
\hline 10 & TZEQI $159 \times$ TZEQI 132 \\
\hline 11 & TZEQI $159 \times$ TZEQI 143 \\
\hline 12 & TZEQI $165 \times$ TZEQI 132 \\
\hline 13 & TZEQI $171 \times$ TZEQI 158 \\
\hline 14 & TZEQI $175 \times$ TZEQI 159 \\
\hline 15 & TZEQI $210 \times$ TZEQI 171 \\
\hline 16 & TZEQI $210 \times$ TZEQI 188 \\
\hline 17 & TZEQI $241 \times$ TZEQI 216 \\
\hline 18 & TZEQI $241 \times$ TZEQI 228 \\
\hline 19 & TZEQI $246 \times$ TZEQI 210 \\
\hline 20 & TZEQI $6 \times$ TZEQI 210 \\
\hline 21 & TZEQI $6 \times$ TZEQI 219 \\
\hline 22 & TZEQI $6 \times$ TZEQI 228 \\
\hline 23 & TZEQI $39 \times$ TZEQI 14 \\
\hline 24 & TZEQI $6 \times$ TZEQI 55 \\
\hline 25 & TZEQI $39 \times$ TZEQI 44 \\
\hline 26 & ENT $3 \times$ TZEI 65 \\
\hline
\end{tabular}

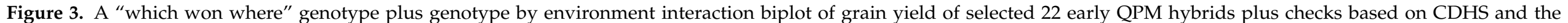

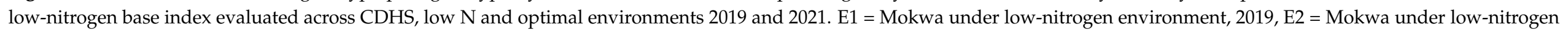

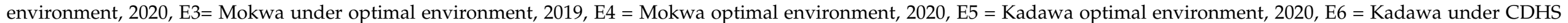
environment, 2020, E7 = Kadawa under CDHS environment, 2021. 


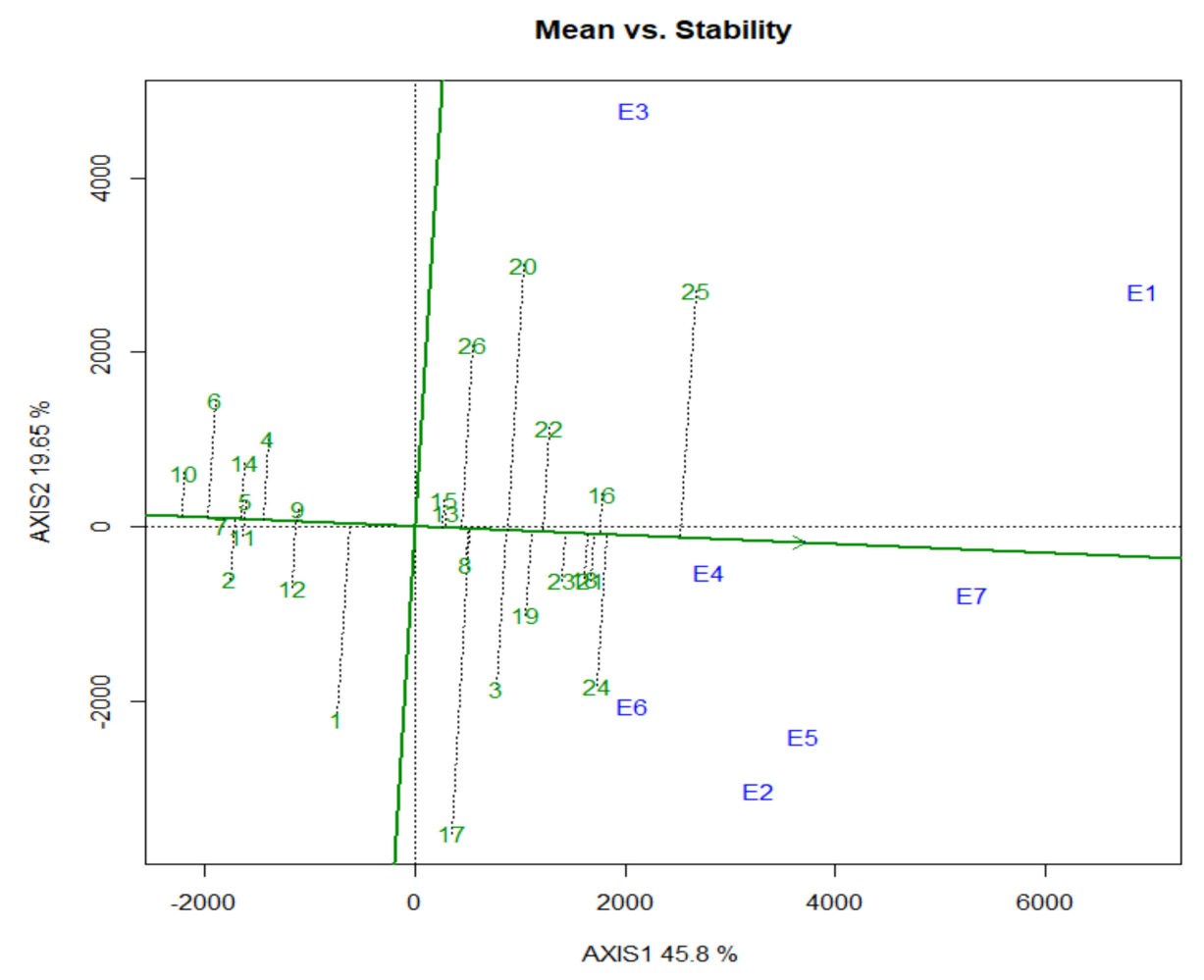

\begin{tabular}{|l|l|}
\hline Entry & Hybrids \\
\hline 1 & TZEQI $106 \times$ TZEQI 6 \\
\hline 2 & TZEQI $113 \times$ TZEQI 240 \\
\hline 3 & TZEQI $113 \times$ TZEQI 6 \\
\hline 4 & TZEQI $130 \times$ TZEQI 123 \\
\hline 5 & TZEQI $132 \times$ TZEQI 113 \\
\hline 6 & TZEQI $132 \times$ TZEQI 122 \\
\hline 7 & TZEQI $140 \times$ TZEQI 106 \\
\hline 8 & TZEQI $140 \times$ TZEQI 113 \\
\hline 9 & TZEQI $143 \times$ TZEQI 122 \\
\hline 10 & TZEQI $159 \times$ TZEQI 132 \\
\hline 11 & TZEQI $159 \times$ TZEQI 143 \\
\hline 12 & TZEQI $165 \times$ TZEQI 132 \\
\hline 13 & TZEQI $171 \times$ TZEQI 158 \\
\hline 14 & TZEQI $175 \times$ TZEQI 159 \\
\hline 15 & TZEQI $210 \times$ TZEQI 171 \\
\hline 16 & TZEQI $210 \times$ TZEQI 188 \\
\hline 17 & TZEQI $241 \times$ TZEQI 216 \\
\hline 18 & TZEQI $241 \times$ TZEQI 228 \\
\hline 19 & TZEQI $246 \times$ TZEQI 210 \\
\hline 20 & TZEQI $6 \times$ TZEQI 210 \\
\hline 21 & TZEQI $6 \times$ TZEQI 219 \\
\hline 22 & TZEQI $6 \times$ TZEQI 228 \\
\hline 23 & TZEQI $39 \times$ TZEQI 14 \\
\hline 24 & TZEQI $6 \times$ TZEQI 55 \\
\hline 25 & TZEQI $39 \times$ TZEQI 44 \\
\hline 26 & ENT $3 \times$ TZEI 65 \\
\hline & \\
\hline
\end{tabular}

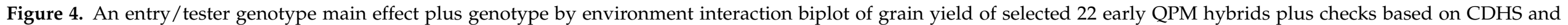

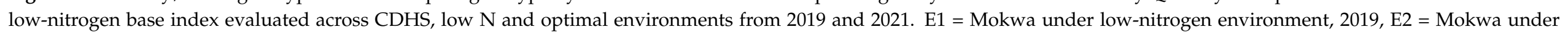

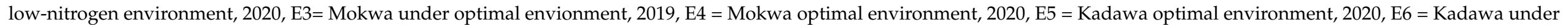
CDHS environment, 2020, E7 = Kadawa under CDHS environment, 2021. 
The "mean vs. stability" of the GGE biplot view was used to identify the highest yielding and the most stable QPM hybrids across the test environments (Figure 4). The vertical line that passed through the biplot origin (intercept of the vertical and horizontal axis) is referred to as the average tester coordinate (ATC). The ATC ordinate separated the low yielding hybrids from the high yielding hybrids. The average yields of the QPM hybrids were determined by the projections from the positions of the hybrids onto the average tester ordinate (ATC ordinate) while the stability of the hybrids was measured by their projections from the average tester coordinate abscissa (ATC abscissa) or the horizontal line. The farther the hybrid from the ATC ordinate, the higher the yield while the shorter or closer the length of the projection of a hybrid to the ATC abscissa, the more stable the hybrid. Based on these criteria, the "mean vs. stability" of the GGE biplot view identified TZEQI $39 \times$ TZEQI 44 (entry 25, a commercial check) as the highest yielding and TZEQI $210 \times$ TZEQI 188 as the most stable QPM hybrid across research environments (Figure 4).

\subsection{Step-Wise Multiple Regression and Sequential Path Analyses}

Under the low-nitrogen environment, plant and ear aspects were identified by the stepwise multiple regression analysis as the first order traits, with significant contributions to grain yield and explaining 73\% of the total variation in the grain yield of the QPM hybrids (Supplementary Figure S1). Plant aspect had the highest direct negative contribution of -0.58 to grain yield. Five traits (stay green characteristic, days to $50 \%$ silking, ear height, ears per plant and plant height) contributed indirectly to grain yield through both plant and ear aspects and were identified as the second order traits. Among the second order traits, days to $50 \%$ silking made the highest positive (0.41) indirect contribution to grain yield through plant aspect. In contrast, ear height made the highest indirect negative contribution to grain yield through plant aspect. Days to 50\% anthesis and ASI were identified as the third order traits. They contributed indirectly to grain yield through ears per plant, ear height, days to 50\% silking and plant height. In the CDHS environment, ear aspect and ear height were identified as the traits with direct contributions to grain yield accounting for $49 \%$ of the total variation in grain yield (Supplementary Figure S2). Ear aspect recorded the highest direct negative contribution $(-0.54)$ to grain yield. Five traits were identified as the second order traits with plant aspect recording the highest indirect positive contribution to grain yield through the ear aspect. Among the third order traits, days to $50 \%$ anthesis had the highest indirect contribution to grain yield through plant aspect. Across stress environments, ear aspect and ear height were identified by the stepwise multiple regression analysis as the first order traits, with significant contributions to grain yield and explaining $55 \%$ of the total variation in the grain yield of the QPM hybrids (Figure 5). Ear aspect had the highest negative effect $(-0.46)$ on grain yield. Seven traits (plant aspect, stay green characteristic, plant height, days to $50 \%$ silking, anthesis-silking interval, ears per plant, and root lodging) were identified as the second order traits. Among the seven traits, plant aspect had the highest indirect contribution of 0.58 and -0.61 to grain yield through ear aspect and ear height, respectively. 


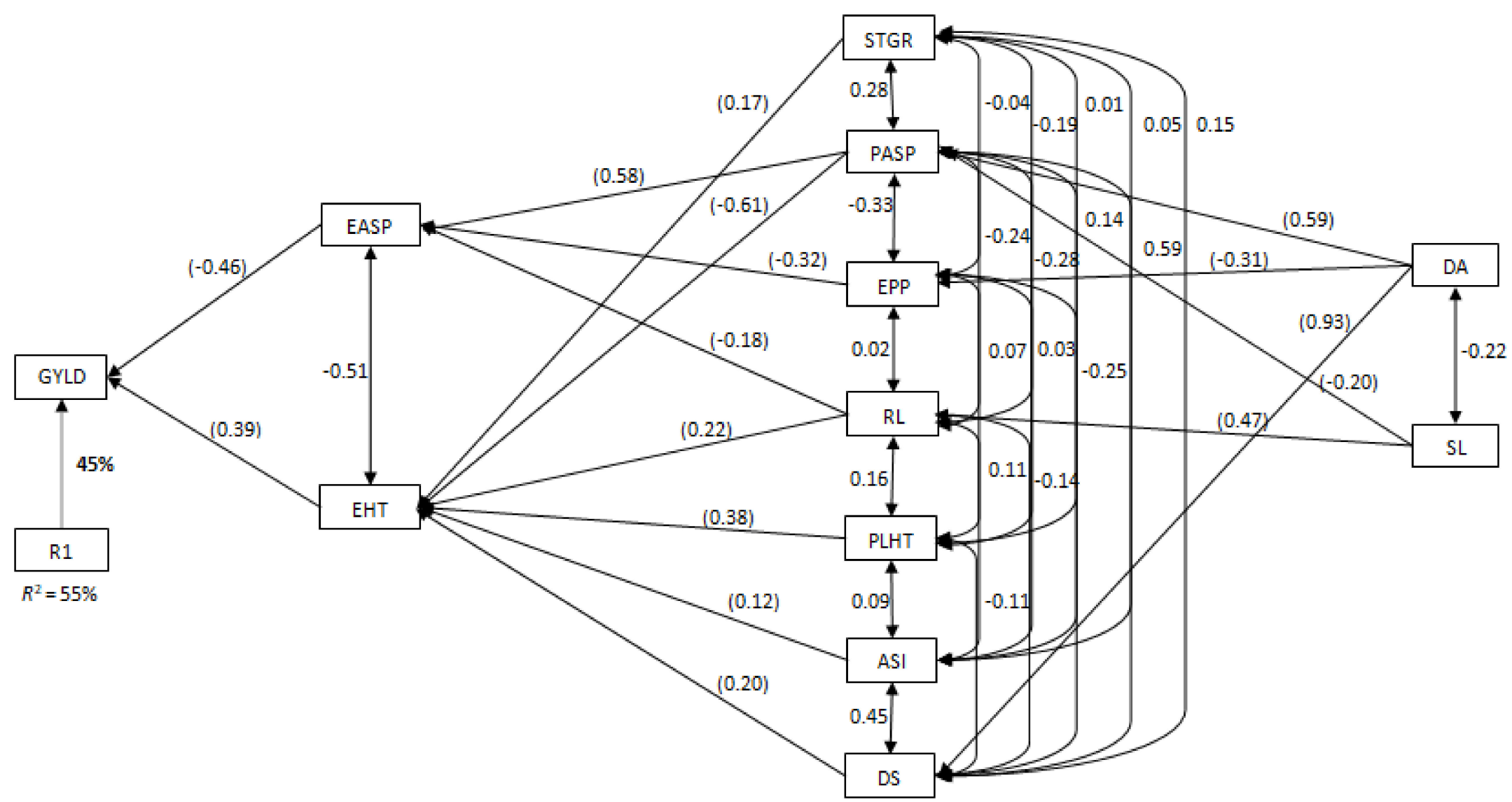

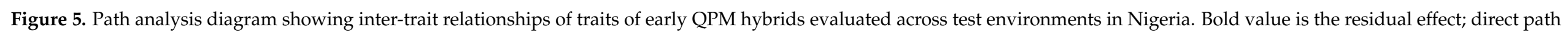

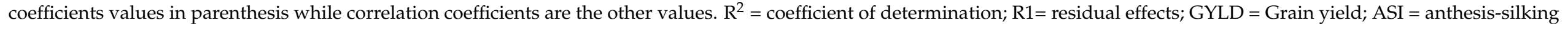

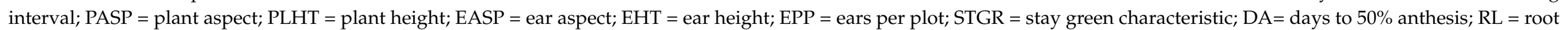
lodging; $\mathrm{DS}=$ days to $50 \%$ silking; $\mathrm{SL}=$ stalk lodging; $\mathrm{TABLAST}=$ tassel blast. 


\section{Discussion}

The significant genotypic variation $(p<0.01)$ observed among the early QPM hybrids under low-nitrogen, CDHS, optimal and across test environments indicated that considerable genetic variation existed among the genotypes to facilitate accelerated gains from selection under contrasting environments. The observed significant differences for environments among the QPM hybrids revealed that each research environment was unique in terms of climatic and edaphic conditions which further suggested the need for extensive evaluations in contrasting environments. The significant genotype by environment interactions observed for grain yield and other measured traits under low-nitrogen, CDHS, optimal environments and across test environments implied that the hybrids responded distinctively to the environments. This emphasized that the environments were different and that the performance of the hybrids would not be consistent in different environments. Similar findings were reported by Ertiro et al. [12], Badu-Apraku et al. [26], Ifie et al. [30] under low-nitrogen and Meseka et al. [21], Nelimor et al. [22] under CDHS environments

Very low heritability estimates were obtained for grain yield, anthesis and silking interval, and stay green characteristic of the QPM hybrids under low-nitrogen and tassel blasting under CDHS environments suggesting that selection based on phenotypic expression of these traits would be ineffective in achieving significant genetic gains. Contrary to the results of the present study, Meseka et al. [21] and Nelimor et al. [22,23] reported relatively moderate heritability estimates for grain yield under CDHS. Additionally, moderate to high repeatability estimates recorded for most measured traits indicated the reliability of the data for the measured traits in the present study [4].

Partitioning the QPM hybrids into genetic components, significant GCAm and GCAf mean squares were observed for grain yield and other measured traits under low-nitrogen environments implied that additive gene action was more important in the inheritance of grain yield and other measured traits under low-nitrogen. Similar findings were reported by Ifie et al. [30], Annor and Badu-Apraku [31], Obeng-Bio et al. [11], and Abu et al. [32] on the preponderance of the additive gene action over the non-additive gene action in the inheritance of grain yield under low-nitrogen environments. Contrarily, studies by Makumbi et al. [33], and Neolle et al. [34] reported non-additive gene action to be more important in the inheritance of grain yield under low-nitrogen environments.

Under CDHS environment conditions, the significant GCAf and SCA mean squares for grain yield and other measured traits, except for GCAm for grain yield, ASI, plant height, plant and ear aspects implied that both the additive and the non-additive gene actions were involved in the inheritance of grain yield and other measured traits under CDHS. Furthermore, the preponderance of SCA variances over GCA variances for grain yield indicated that non-additive gene action was more important than the additive and that the non-additive gene action was more important for the inheritance of grain yield traits under CDHS. This result is consistent with the findings of Chiuta and Mutengwa [24] who reported the preponderance of the non-additive gene action over the additive in the inheritance of grain yield under CDHS environments. Contrarily, Nasser et al. [29] reported the preponderance of the additive gene action over the non-additive in the inheritance of grain yield under CDHS environments.

The significant GCAm, GCAf and the SCA mean squares for grain yield and other measured traits under optimal environments, except the GCAm for ASI and ear rot as well as the GCAf and the SCA for grain yield and ear rot, indicated that both the additive and the non-additive gene action were important in the inheritance of grain yield and other measured traits under optimal environments. The larger GCAm and GCAf mean squares for grain yield compared to the SCA mean squares, indicated that the additive gene action was more important in the inheritance of grain yield under optimal environments. This result is consistent with the findings of Makumbi et al. [33], Noelle et al. [34], Oyekale et al. [37], and Chiuta and Mutengwa [24] who reported that additive gene action controlled grain yield under optimal conditions. 
The non-significant SCA mean squares recorded for the stay-green characteristic under low-nitrogen and CDHS environments indicated that the non-additive gene action was not important in the inheritance of the stay-green characteristic in this study. This result is similar to the findings of Badu-Apraku et al. [38] and Ifie et al. [30] who reported non-significant SCA mean squares for the stay-green characteristic under low-nitrogen conditions. However, the significant GCAm mean squares observed for the stay green characteristic under low-nitrogen and the significant GCAm and GCAf mean squares observed for the stay green characteristic under CDHS, indicated that there were variations in the expression of the QPM inbreds as parents in hybrid combinations for the stay green characteristic under CDHS conditions. Similar results were reported by Annor and Badu-Apraku [31] and Badu-Apraku et al. [26] who reported significant GCAm and GCAf effects for stay green characteristic under drought and low-nitrogen environments. The implications of these results are that recurrent selection methods should be the most effective for increasing the frequency of favourables alleles in a breeding population for the development of synthetic varieties. Contrarily, the preponderance of non-additive gene action implied that hybrid development should be employed under CDHS to exploit heterotic potentials of the QPM inbred lines. The differences in the results of the different authors could be attributed to differences in the germplasm studied, the statistical model employed, the severity of stress levels imposed and the experimental mating design used $[4,26]$.

The non-significant GCAm $\times$ environment $(\mathrm{E}), \mathrm{GCAf} \times$ environment $(\mathrm{E})$ and SCA $\times$ environment $(\mathrm{E})$ interactions observed for measured traits except the GCAm $\times \mathrm{E}$ for ASI and the GCAf $\times$ E for grain yield under low-nitrogen conditions, indicated that the performance of the parental lines were consistent across the low-nitrogen environments. This result is in agreement with the findings of Derera et al. [39] and Oyekale et al. [37] who reported non-significant GCAm $\times \mathrm{E}, \mathrm{GCAf} \times \mathrm{E}$ and SCA $\times \mathrm{E}$ interactions for grain yield under drought and low-nitrogen environments. Contrarily, Annor and Badu-Apraku [31] and Badu-Apraku et al. [26] reported significant GCAm $\times \mathrm{E}, \mathrm{GCAf} \times \mathrm{E}$ and SCA $\times \mathrm{E}$ interactions for grain yield and other measured traits of extra-early and early QPM inbreds under low-nitrogen stress. Similarly, Obeng-Bio et al. [11] reported significant GCAm $\times$ E, GCAf $\times$ E and SCA $\times$ E interactions for grain yield and other traits in early pro-vitamin A (PVA) QPM inbred lines under low-nitrogen. The significant GCAf $\times$ E interaction for grain yield suggested that the GCA effects associated with the female parents were not the same across the low-nitrogen environments.

Under low-nitrogen environments, comparable contributions of GCAm and GCAf sum of squares were observed for grain yield and other measured traits except ASI, indicating that both maternal and paternal effects were equally important in the inheritance of the measured traits of the hybrids. Similar studies by Ifie et al. [30], Annor and BaduApraku [31], Obeng-Bio et al. [11] reported no significant differences in the contribution of both GCAm and GCAf (paternal and maternal effects) for grain yield and other measured traits under low-nitrogen. However, GCAm for ASI was larger than GCAf, suggesting the importance of paternal effects in the inheritance of anthesis and silking interval. The larger GCAf sum of squares relative to GCAm sum of squares observed under CDHS environments for grain yield and plant aspect indicated the greater importance of cytoplasmic effect on the inheritance of grain yield and plant aspect. Also, ears per plant had significantly larger GCAf sum of squares than the GCAm sum of squares indicating that maternal effects conditioned prolificacy and that the parental lines with significant and positive GCAf effects for ears per plant should be used as the female parents in hybrid production to ensure prolificacy under CDHS.

According to Girma et al. [40], the information on the combining of ability of parental lines for a trait is useful in determining the contribution of the parental lines to their progenies in hybrid combinations. In other words, parental lines with significant GCA effect for a trait under a stress condition has high probability of transferring the favourable alleles for the trait to progenies in hybrid combinations and such parental lines could 
be useful in the development of outstanding hybrids [4]. The observed significant and positive GCAm and GCAf effects for grain yield recorded by TZEQI 6 under low-nitrogen environments indicated that the parental line would transfer favourable alleles to the progeny when used either as a female or a male parent. Similarly, the significant and positive GCAm effects for grain yield recorded by TZEQI 106, TZEQI 113, TZEQI 158, TZEQI 188 and TZEQI 6 under low-nitrogen environments suggested that these inbred lines when used as male parents, would transfer favourable alleles for grain yield to their progenies under low-nitrogen environments. A similar inference could be made for the inbred TZEQI 210 which displayed significant and positive GCAf effects for grain yield. Additionally, the observed significant and positive GCAm effects for grain yield by TZEQI 113 and TZEQI 216 implied that both parental lines would transfer favourable alleles to their progenies when used as male parents under CDHS environment. In addition, the significant and negative GCAf effects observed for stay green characteristic was an indication that TZEQI 6, TZEQI 113, TZEQI 132, TZEQI 158 and TZEQI 219 would contribute favourable alleles to their progenies for delayed senescence or prolonged stay green characteristic, increased photosynthesis and assimilate production under low-nitrogen conditions.

Using the HGCAMT grouping method, the 24 QPM inbred lines were classified into four heterotic groups. Interestingly, crosses between inbred lines from different heterotic groups displayed higher heterosis across stress environments indicating the effectiveness of the grouping method. The heterotic groups identified by the HGCAMT method across environments would increase the chances of developing outstanding early maturing QPM hybrids and synthetics with CDHS and low-nitrogen tolerance for commercialization in SSA. Additionally, heterotic populations could be developed by recombining QPM inbred lines from the same heterotic group and improving the population through recurrent selection methods [41].

Based on the criteria proposed by Pswarayi and Vivek [36] for identifying inbred and single-cross testers, inbred line TZEQI 6 with significant and positive GCAm and GCAf effects for grain yield was identified as a tester under low-nitrogen environment conditions, suggesting that TZEQI 6 was a good combiner and could be used either as a male or a female parent in the development of high yielding hybrids and for grouping of other inbred lines under low-nitrogen environments. This result confirmed the earlier report by Badu-Apraku and Fakorede [4] who identified TZEQI 6 as a tester. It was therefore, not surprising that TZEQI 6 was involved in the following outstanding hybrid combinations: TZEQI $6 \times$ TZEQI 228, TZEQI $113 \times$ TZEQI 6, TZEQI $6 \times$ TZEQI 210 and TZEQI $6 \times$ TZEQI 219. Hybrid TZEQI $113 \times$ TZEQI 6 was identified as a single-cross tester and could be used for the development of three-way and double-cross hybrids [26].

An important objective of this study was to identify the most outstanding hybrids under each and across test environment conditions. The QPM hybrids TZEQI $6 \times$ TZEQI 219 and TZEQI $6 \times$ TZEQI 228 were identified as the most outstanding across CDHS and low-nitrogen environments. These hybrids could be useful in the development of early maturing multiple-stress tolerant three-way QPM hybrids for commercialization in SSA.

The significant genotype by environment interaction observed for grain yield under CDHS, low-nitrogen and across test environments in the present study justified the use of the GGE biplot to identify high yielding and stable QPM hybrids for commercialization in SSA. From the "which-won-where" view of the GGE biplot, hybrids TZEQI $241 \times$ TZEQI 216, TZEQI $6 \times$ TZEQI 210, TZEQI $39 \times$ TZEQI 44 (check) and TZEQI $6 \times$ TZEQI 55 (check) were identified as the highest yielding in low-nitrogen, optimal and CDHS environments, respectively. Additionally, the mean yield vs. stability of the GGE biplot view identified TZEQI $39 \times$ TZEQI 44 (check) as the highest yielding and TZEQI 210 $\times$ TZEQI 188 as the most stable QPM hybrids across test environments. These results suggested that these hybrids would display superior performance in nitrogen depleted, drought prone environments without compromising grain yield. 
Because of the quantitative nature of grain yield and the low heritability recorded for grain yield under the stress environment conditions used in this study, selection using grain yield alone without other agronomic traits would be ineffective [42]. Therefore, there was the need to examine the interactions among the secondary traits and their relative contribution to grain yield for effective selection. Under low-nitrogen conditions, plant and ear aspects were identified as the most important secondary traits contributing to the observed variations in grain yield, thus suggesting their reliability as secondary traits for selection under low-nitrogen environments. In an earlier study, Badu-Apraku et al. [43] using sequential path analysis, identified plant and ear aspects as the first order traits with direct contribution to grain yield under low-nitrogen environments. Additionally, the stay green characteristic contributed indirectly to grain yield through both plant and ear aspects, indicating its reliability as a secondary trait thus justifying its inclusion in the selection base index under low-nitrogen environments. Under CDHS environments, the direct contributions of both ear aspect and ear height to grain yield indicated that they were the major determinants of grain yield. Plant aspect contributed indirectly to grain yield through the two first order traits (ear aspect and ear height), indicating its importance in the selection of genotypes under CDHS environments. Similarly, both ear aspect and ear height had direct contributions to grain yield across test environments, implying that they were the major contributors to grain yield. These results justified the inclusion of plant and ear aspects in the selection index under both stress conditions. Additionally, this suggested the need to revisit the issue of the inclusion of ear height as one of the secondary traits in the selection index under stress environments. However, increasing ear height is not desirable because it is associated with stalk lodging. Therefore, in the IITA-MIP plant and ear heights are usually pegged and not allowed to increase.

\section{Materials and Method}

\subsection{Genetic Materials and Testcrosses}

The genetic materials used in this study comprised twenty-four early white QPM inbred lines extracted from $\mathrm{F}_{1}$ maize hybrids of ten bi-parental crosses involving crosses among extra-early white QPM inbred testers and early maturing white QPM inbred testers. The QPM inbred line testers were identified to have positive and significant general combining ability from previous studies $[4,26]$ (the $F_{1}$ hybrids were taken through a cycle of backcrossing to the extra-early inbred testers to recover the earliness. The $\mathrm{BC}_{1} \mathrm{~F}_{1}$ with desirable agronomic characteristics were selected using pedigree selection from each backcrossed population and advanced through repeated inbreeding to the $S_{7}$ generation while selecting for kernels with the appropriate endosperm modification ranging from $25-50 \%$ (Table 1). The 24 inbred lines were selected based on their reactions to lownitrogen and CDHS in the preliminary evaluations (Table 6). The inbred lines were intermated to generate 96 F1 hybrids using the North Carolina II mating Design (NCDII) proposed by Comstock and Robinson [44]. This was achieved by dividing the QPM inbred lines into six sets each comprising four early QPM inbred lines. Each inbred line was used as a male in one set and as a female in another set, to produce a total of six sets each containing four inbred lines, resulting in a total of 96 design II single-cross hybrids (Supplementary Table S1). 
Table 6. List of the 24 early QPM inbred lines used in the North Carolina design II mating design to generate the 96 single-cross hybrids.

\begin{tabular}{|c|c|c|c|c|c|}
\hline $\mathrm{S} / \mathbf{N}$ & INBREDS & PEDIGREE & $\begin{array}{l}\text { Reaction to } \\
\text { Low-Nitrogen }\end{array}$ & $\begin{array}{l}\text { Reaction to } \\
\text { CDHS }\end{array}$ & SET \\
\hline 1 & TZEQI 106 & (TZEEQI 7 × TZEQI 6)F1 4/13 BC1 S7 1/2 $-1 / 1-3 / 4-3 / 3-2 / 2^{-1} / 1^{-1} / 1$ & S & S & A \\
\hline 2 & TZEQI 113 & (TZEEQI $7 \times$ TZEQI 6)F1 $4 / 13$ BC1 S7 2/2-2/3-1 $/ 4-5 / 5-2 / 8^{-1} / 1^{-1} / 1$ & $\mathrm{~S}$ & $\mathrm{~T}$ & A \\
\hline 3 & TZEQ̈I 122 & (TZEEQI 7 × TZEQI 6 )F1 4/13 BC1 S7 2/2-2/3-4/4-6/6-3/4 $4^{-1} / 2^{-1} / 1$ & $\mathrm{~T}$ & $\mathrm{~T}$ & A \\
\hline 4 & TZEQ̈I 123 & (TZEEQI $7 \times$ TZEQI 6)F1 4/13 BC1 S7 2/2-2/3-4/4-6/6-4/4-1/1 $1^{-1} / 1$ & $\mathrm{~T}$ & $\mathrm{~S}$ & A \\
\hline 5 & TZEQI 130 & (TZEEQI $7 \times$ TZEQI 6$)$ F1 10/13 BC1 S7 $1 / 3^{-1} / 1-3 / 5-2 / 3-3 / 3^{-1} / 1^{-1} / 1$ & $\mathrm{~T}$ & $\mathrm{~T}$ & $\mathrm{~B}$ \\
\hline 6 & TZEQI 132 & (TZEEQI $7 \times$ TZEQI 6 )F1 10/13 BC1 S7 $2 / 3^{-1} / 1-3 / 5^{-1} / 2^{-1} / 2^{-1} / 1^{-1} / 1$ & $\mathrm{~S}$ & $\mathrm{~S}$ & B \\
\hline 7 & TZEQI 140 & (TZEEQI $7 \times$ TZEQI 6)F1 $12 / 13$ BC1 S7 $1 / 2^{-1} / 1^{-1} / 3^{-1} / 4^{-1} / 2^{-1} / 1^{-1} / 1$ & $\mathrm{~T}$ & $\mathrm{~S}$ & $\mathrm{~B}$ \\
\hline 8 & TZEQI 143 & (TZEEQI $7 \times$ TZEQI 6$) \mathrm{F} 1$ 13/13 BC1 S7 $1 / 2^{-1} / 1^{-1} / 3-3 / 3-2 / 3^{-1} / 1^{-1} / 1$ & $\mathrm{~S}$ & S & B \\
\hline 9 & TZEQ̈I 158 & $\left(\right.$ TZEEQI $7 \times$ TZEQI 4)F1 2/10 BC1 S7 $1 / 2^{-1} / 3-2 / 3-2 / 3-2 / 3^{-1} / 1^{-1} / 1$ & $\mathrm{T}$ & $\mathrm{S}$ & $\mathrm{C}$ \\
\hline 10 & TZEQ̈I 159 & (TZEEQI $7 \times$ TZEQI 4)F1 2/10 BC1 S7 $1 / 2^{-1} / 3-2 / 3-2 / 3-3 / 3^{-1} / 1^{-1} / 1$ & $\mathrm{~T}$ & $\mathrm{~T}$ & $\mathrm{C}$ \\
\hline 11 & TZEQI 162 & (TZEEQI $7 \times$ TZEQI 4)F1 2/10 BC1 S7 $1 / 2-3 / 3^{-1} / 4-5 / 5^{-1} / 2^{-1} / 1^{-1} / 1$ & $\mathrm{~T}$ & $\mathrm{~T}$ & $\mathrm{C}$ \\
\hline 12 & TZEQ̈I 165 & (TZEEQI $7 \times$ TZEQI 4)F1 2/10 BC1 S7 $1 / 2-3 / 3-3 / 4-3 / 4-2 / 4^{-1} / 1^{-1} / 1$ & $\mathrm{~S}$ & S & $\mathrm{C}$ \\
\hline 13 & TZEQI 171 & $($ TZEEQI $7 \times$ TZEQI 4$) F 13 / 10$ BC1 S7 $1 / 2^{-1} / 2^{-1} / 1-2 / 2^{-1} / 3^{-1} / 1^{-1} / 1$ & S & $\mathrm{T}$ & $\mathrm{D}$ \\
\hline 14 & TZEQ̈I 175 & (TZEEQI $7 \times$ TZEQI 4)F1 3/10 BC1 S7 $2 / 2-2 / 3^{-1} / 1^{-1} / 4^{-1} / 3^{-1} / 2^{-1} / 1$ & $\mathrm{~S}$ & $\mathrm{~T}$ & $\mathrm{D}$ \\
\hline 15 & TZEQI 176 & (TZEEQI $7 \times$ TZEQI 4)F1 3/10 BC1 S7 $2 / 2-2 / 3^{-1} / 1^{-1} / 4-2 / 3^{-1} / 2^{-1} / 1$ & $\mathrm{~T}$ & $\mathrm{~S}$ & $\mathrm{D}$ \\
\hline 16 & TZEQI 188 & (TZEEQI $7 \times$ TZEQI 4 )F1 3/10 BC1 S7 3/3 $3^{-1} / 4-5 / 6^{-1} / 3-2 / 2^{-1} / 1^{-1} / 1$ & $\mathrm{~T}$ & $\mathrm{~S}$ & $\mathrm{D}$ \\
\hline 17 & TZEQI 210 & (TZEEQI $102 \times$ TZEQI 6 )F1 2/11 BC1 S7 $2 / 2^{-1} / 1^{-1} / 4^{-1} / 3^{-1} / 2^{-1} / 1^{-1} / 1$ & $\mathrm{~S}$ & $\mathrm{~T}$ & E \\
\hline 18 & TZEQ̃I 216 & (TZEEQI $102 \times$ TZEQI 6 )F1 9/11 BC1 S7 $1 / 3-2 / 2^{-1} / 2-2 / 2-2 / 2^{-1} / 1^{-1} / 1$ & $\mathrm{~S}$ & $\mathrm{~T}$ & $\mathrm{E}$ \\
\hline 19 & TZEQI 219 & (TZEEQI $7 \times$ TZEQI 60 )F1 $2 / 17$ BC1 S7 $2 / 2^{-1} / 1-2 / 3^{-1} / 1^{-1} / 3^{-1} / 1^{-1} / 1$ & $\mathrm{~S}$ & $\mathrm{~T}$ & $\mathrm{E}$ \\
\hline 20 & TZEQI 228 & (TZEEQI $137 \times$ TZEQI 49)F1 2/9 BC1 S7 $2 / 2^{-1} / 2^{-1} / 3-2 / 2-2 / 2^{-1} / 1^{-1} / 1$ & $\mathrm{~S}$ & $\mathrm{~T}$ & E \\
\hline 21 & TZEQI 240 & (TZEEQI $7 \times$ TZEQI 6)F1 4/13 BC1 S7 $1 / 2^{-1} / 1^{-1} / 2-4 / 4-2 / 2^{-1} / 1^{-1} / 1$ & $\mathrm{~T}$ & $\mathrm{~S}$ & $\mathrm{~F}$ \\
\hline 22 & TZEQI 241 & (TZEEQI $7 \times$ TZEQI 6)F1 4/13 BC1 S7 2/2-2/3-2/4-1/6-2/3 $3^{-1} / 1^{-1} / 1$ & $\mathrm{~T}$ & $\mathrm{~T}$ & $\mathrm{~F}$ \\
\hline 23 & TZEQ̄I 246 & (TZEEQI $7 \times$ TZEQI 4 )F1 3/10 BC1 S7 3/3 $3^{-1} / 4-3 / 6-2 / 3^{-1} / 3^{-1} / 1^{-1} / 1$ & $\mathrm{~T}$ & $\mathrm{~S}$ & $\mathrm{~F}$ \\
\hline 24 & TZEQI 6 & CHECK & $\mathrm{S}$ & $\mathrm{S}$ & $\mathrm{F}$ \\
\hline
\end{tabular}

\subsection{Experimental Sites and Field Evaluation}

The 96 early white QPM hybrids generated from the crosses of the 24 QPM inbred lines and four released IITA commercial hybrid checks (Supplementary Table S2) were evaluated using a $10 \times 10$ lattice design with two replications at the IITA experimental station, Mokwa, Nigeria $\left(9^{\circ} 18^{\prime} \mathrm{N}, 5^{\circ} 4^{\prime} \mathrm{E}, 457 \mathrm{~m}\right.$ altitude, $1100 \mathrm{~mm}$ annual rainfall) during the 2019 and 2020 rainy season (between June and October). The low-nitrogen experiment was carried out at Mokwa where the soil had been depleted of nitrogen by the continuous growing of maize without the application of fertilizer and the removal of the biomass after each cropping season. Therefore, the low-nitrogen blocks were depleted of nitrogen to zero level. During each season, three seeds were planted per hill and seedlings were thinned to two plants per hill 2 weeks after planting (WAP) to obtain the target population density of 66,666 plants ha ${ }^{-1}$. The seeds were planted in single-row plots of $3 \mathrm{~m}$ long with spacing of $0.75 \mathrm{~m}$ and $0.40 \mathrm{~m}$ between and within rows, respectively. The nitrogen fertilizer in the form of urea $\left(30 \mathrm{~kg} \mathrm{~N} \mathrm{ha}^{-1}\right)$ and $15 \mathrm{~kg} \mathrm{~N} \mathrm{ha}^{-1}$ were applied at 2 WAP with additional $15 \mathrm{~kg} \mathrm{~N} \mathrm{ha}^{-1}$ applied at 4 WAP. The low-nitrogen plots received $60 \mathrm{~kg} \mathrm{ha}^{-1}$ each of single superphosphate (P2O5) and muriate of potash $\left(\mathrm{K}_{2} \mathrm{O}\right)$ at 2 WAP. The low-nitrogen plots were kept weed-free with the application of atrazine and gramozone as pre- and post-emergence herbicides at $5 \mathrm{~L} / \mathrm{ha}$, respectively, and subsequently supplemented with hand weeding to keep the plots weed-free.

The 96 early white QPM hybrids plus four hybrid checks were also evaluated for their agronomic performance under CDHS conditions at the IITA experimental station in Kadawa $\left(11^{\circ} 45^{\prime} \mathrm{N}, 8^{\circ} 45^{\prime} \mathrm{E}, 468.5 \mathrm{~m} \mathrm{ASL}, 884 \mathrm{~mm}\right.$ annual rainfall) during the 2020 and 2021 dry seasons, where extreme drought stress at high temperatures between 33 and $45{ }^{\circ} \mathrm{C}$ occurred between February and June every year [20] (Supplementary Figure S3). The CDHS trials were irrigated twice every week for the first 28 days after planting using a furrow irrigation system with the plants relying on the stored soil moisture. The plants were subjected to CDHS for 3 weeks during the month of April when the day temperature varied from 35 to $40{ }^{\circ} \mathrm{C}$ with the night temperature ranging from 22 to $28{ }^{\circ} \mathrm{C}$ [4,20]. A $10 \times 10$ alpha-lattice design with two replicates were used for the evaluation of the 100 Design II single-cross hybrids. The experimental units were one-row plots; each $3 \mathrm{~m}$ long with row spacing of $0.75 \mathrm{~m}$ and the distance between two adjacent plants within the rows were $0.40 \mathrm{~m}$ in all trials. The trials were kept weed free through the application 
of atrazine and gramozone as pre- and post-emergence herbicides supplemented with manual weeding.

The QPM hybrids were also evaluated using $10 \times 10$ lattice design with two replications respectively under optimal conditions at Mokwa and Kadawa during the 2019/2020 (between June and October) rainy seasons. Fertilizer was applied at the rate of $30 \mathrm{~kg} \mathrm{~N} \mathrm{ha}^{-1}, 60 \mathrm{~kg} \mathrm{ha}^{-1}$ each of $\mathrm{P} 2 \mathrm{O} 5$ and $\mathrm{K}_{2} \mathrm{O}$ at 2 WAP and additional $60 \mathrm{~kg} \mathrm{ha}^{-1} \mathrm{~N}$ was top-dressed using urea at 4 WAP. The trials were kept weed free as described in the other trials.

\subsection{Data Collection}

Data were collected under each research conditions for number of days to $50 \%$ silking (DS) and anthesis (DA). Anthesis-silking interval (ASI) was calculated as the difference between DS and DA. Plant height (PLHT) was measured as the distance from the base of the plant to the height of the first tassel branch. Ear height (EHT) was measured in centimetres as the distance from the base of the plant to the node bearing the upper ear. Root lodging (RL) was measured as the percentage of plants leaning more than $30^{\circ}$ (degree) from the vertical whereas stalk lodging (SL) was recorded as the percentage of plants broken at or below the highest ear node. Plant aspect (PASP) was recorded on a scale of 1 to 9 based on plants appeal to sight, where $1=$ excellent phenotypic appeal and $9=$ extremely poor phenotypic appeal. Ear aspect (EASP) assessed the freedom from disease and insect damage; ear size and uniformity of ears was scored on a scale of 1 to 9 , where $1=$ large, uniform, clean, and well-filled ears and $9=$ ears with totally unattractive features. Number of ears per plant (EPP) was calculated by dividing the total number of ears harvested per plot (EHARV) by the number of plants in a plot at harvest (PHARV). Ear rot (EROT) was computed as the percentage of ears harvested that had ear rot. Stay green (STGR) characteristic was scored at $70 \mathrm{DAP}$ on a 1 to 9 scale as percentage of dead leaf area under low-nitrogen and CDHS conditions, where, $1=$ all leaves are green and $9=$ all leaves are dead. Data on tassel blast (TABLAST) and leaf firing were recorded during flowering on the CDHS trial. TABLAST was rated during flowering on a scale of 1 to 9 , where $1=$ all plants had normal pollen production and $9=$ all plants had white, dry tassels without pollen production and showed severe tassel blast.

\subsection{Data Analysis}

Data obtained for grain yield and other measured agronomic traits under low-nitrogen and CDHS environments were subjected to analysis of variance (ANOVA) with PROC GLM statement in SAS version 9.4 [45] to obtain mean squares for each trait. Each yearlocation combination constituted a test environment. In the combined ANOVA, test environments, replications, genotype $\times$ environment interactions, and all other sources of variation were considered as random effects while genotypes were considered as fixed effects. The NCD II analysis of variance for each environment was conducted on the genotypes excluding the checks using PROC GLM statement in SAS [44]. The hybrids component of variation was partitioned into sources of variation and main effects as male(sets) (GCAm), female(sets) (GCAf), and female $\times$ male(sets) (SCA) interaction as described by Hallauer and Miranda [46]. The F tests for male(sets), female(sets), and female $\times$ male(sets) mean squares were estimated using the mean squares of the respective interactions with environment. The mean squares attributable to male $\times$ female (sets) $\times$ environment were tested using the pooled error mean squares. The broad-sense heritability $\left(\mathrm{H}^{2}\right)$ estimates for each measured trait was calculated for each measured traits under each environment, and across the environments were estimated as follows:

$$
\mathrm{H}^{2}=\frac{\sigma_{\mathrm{g}}^{2}}{\sigma_{\mathrm{g}}^{2}+\frac{\sigma_{\mathrm{e}}^{2}}{\mathrm{r}}}
$$

where $\sigma_{\mathrm{g}}^{2}$ is the genotypic variance, $\sigma_{\mathrm{e}}^{2}$ is experimental error variance; and $\mathrm{r}$ is the number of replicates within each test environment [47]. Repeatability estimates were assessed as 
the consistency of the expression of the measured traits across the different environments and the data from a location with repeatabilty estimate of below 30\% was discarded as not reliable $[4,48]$. Thus, repeatability estimates were calculated on a genotype-mean basis as follows:

$$
R=\frac{\sigma_{g}^{2}}{\sigma_{g}^{2}+\frac{\sigma_{g e}^{2}}{e}+\frac{\sigma^{2}}{r e}}
$$

where $\sigma_{g}^{2}$ is the genotypic variance, $\sigma_{g e}^{2}$ is the variance attributable to genotype by environment interaction, $\sigma^{2}$ is the error variance, $r$ is the number of replication and $e$ is the number of environments.

\subsection{The Proportionate Contribution of Combining Ability}

The proportionate contribution for each measured trait was calculated as the percentage of the sum of squares for the crosses attributed to general combining ability (GCA) and specific combining ability (SCA). The general combining ability (GCA) effects for male and female within sets (GCAm and GCAf) for each measured trait were computed from the adjusted means using line $\times$ tester approach [49]. As shown below:

$$
\begin{aligned}
\text { GCAf } & =X_{f}-\mu, \\
\text { GCAm } & =X_{m}-\mu
\end{aligned}
$$

where, GCAm and GCAf were the general combining ability effects of male and female parents respectively, $X_{f}$ and $X_{m}$ were the mean performance of the male and female parents respectively and $\mu$ is the overall mean of crosses in the trial.

The standard errors for GCA effects were calculated as described by Cox and Frey [50]:

$$
\begin{gathered}
\mathrm{SE}(\mathrm{GCAf})=\left[\mathrm{MS}_{\mathrm{fe}}\left(\mathrm{f}^{-1}\right) / f \times e \times r\right]^{1 / 2} \\
\mathrm{SE}(\mathrm{GCAm})=\left[\mathrm{MS}_{\mathrm{me}}\left(\mathrm{m}^{-1}\right) / m \times e \times r\right]^{1 / 2}
\end{gathered}
$$

where, $\mathrm{MS}_{\mathrm{fe}}$, and $\mathrm{MS}_{\mathrm{me}}$ were the mean squares of the interactions between male and female with the environment; $\mathrm{MS}_{\mathrm{fme}}=$ was the mean squares of the female $\times$ male by environment interaction. $m, f, e$, and $r$ are the numbers of male, females, environments, and replicates, respectively.

\subsection{Heterotic Grouping of the Inbred Lines}

Classifying newly developed early maturing QPM inbred lines into appropriate heterotic groups is important for the exploitation of maximum heterosis through crossing of inbreds from opposing heterotic groups [41]. The 24 inbred lines were classified into heterotic groups using the heterotic grouping method based on GCA effects of multiple traits (HGCAMT) method proposed by Badu-Apraku et al. [26]. The GCA effects of traits with significant mean squares for genotype under low-nitrogen, CDHS, optimal and across stress conditions were standardized to minimize the effects of different traits scale. The standardized GCA effects values were subjected to Ward's minimum variance cluster analysis using SAS version 9.4 [45] as described by Badu-Apraku et al. [26].

\subsection{Identification of Inbred and Single-Cross Testers}

An inbred line was identified as a tester based on the following criteria proposed by Pswarayi and Vivek, [36]: it should (i) belong to a heterotic group; (ii) have a significant and positive GCA effects across the test environments and (iii) have a high per-se yield performance. To identify a single-cross tester, the parental lines of the hybrid must: (i) record significant and positive GCA effects for grain yield, (ii) the parental lines of the hybrid should belong to the same heterotic group, and (iii) the hybrid should have relatively good yielding ability under stress conditions. To identify promising hybrids with high grain yield and tolerance to low soil nitrogen and CDHS among the hybrids, a multiple trait base 
index (MI) proposed by Badu-Apraku et al. [26,51] was adopted. The MI integrated grain yield, number of ears per plant, plant aspect, ear aspect, anthesis silking interval as well as the stay green characteristic as follows:

Multiple trait base index $(\mathrm{MI})=[(2 \times \mathrm{GYLD})+\mathrm{EPP}-\mathrm{ASI}-\mathrm{PASP}-\mathrm{EASP}-\mathrm{STGR}]$

where: GYLD = grain yield, EASP = ear aspect, ASI = anthesis-silking interval, EPP = ears per plant, PASP = plant aspect, and STGR = stay green characteristic for the low-nitrogen and the CDHS environments. The parameters used in MI were standardized to reduce the effects of different scales of the parameters. A positive value of the MI was an indicator of CDHS and low-nitrogen tolerance, while a negative value indicated hybrid susceptibility.

\subsection{Stability of Hybrids across Test Environments}

A set of 22 QPM hybrids (top 12 and worst 10) including the four QPM hybrid checks were selected under CDHS and low-nitrogen conditions using the multiple trait selection base index values for the genotype main effect plus genotype by environment interaction (GGE) biplot analysis to separate the genotype by environment interactions into the component parts $[52,53]$. The GGE biplot was used to obtain information on the high yielding and most stable hybrids across test environments using the genotype by environment analysis with R for Windows (GEA-R) software [54]. The "mean vs. stability" view of the GGE biplot was employed to identify hybrids with high grain yield and stability across CDHS, low-nitrogen and optimal environments. The GGE biplot model equation used was as follows:

$$
Y_{i j}-Y_{j}=\lambda_{1} \varepsilon_{i 1} \eta_{j 1}+\lambda_{2} \varepsilon_{i 2} \eta_{j 2}+\varepsilon_{i j}
$$

where, $Y_{i j}$ is the average yield of genotype $i$ in environment $j, Y_{j}$ is the average yield across genotypes in environment $j, \lambda_{1}$ and $\lambda_{2}$ are the singular values for PC1 and PC2 respectively, $\varepsilon_{i 1}$ and $\varepsilon_{i 2}$ are the PC1 and PC2 scores for genotype $i, \eta_{j 1}$ and $\eta_{j 2}$ are the PC1 and PC2 scores for genotype $j, \varepsilon_{i j}$ is the error associated with the genotype $i$ in environment $j$.

\subsection{Inter-Trait Relationships under CDHS and Low-Nitrogen Environments}

The step-wise multiple regression and sequential path diagrams were employed to determine the causal relationships between the measured traits under CDHS and lownitrogen environments using the procedure described by Mohammadi et al. [55]. The step-wise multiple regression analysis was done using the Statistical Package for the Social Sciences, SPSS v. 17.0 [56] to determine the first, second, third, and fourth order predictor traits on the basis of their contributions to grain yield variation. The secondary traits were regressed on grain yield to identify first order traits that contributed significantly to grain yield at $P \leq 0.05$. The remaining secondary traits were regressed on the first order traits to identify those with significant contributions to grain yield and they were categorized as second order traits. The procedure was repeated in order to categorize the remaining traits into subsequent orders. The standardized $b$ values generated by the step-wise regression analysis were the path coefficients $[42,55]$. The significance of a path coefficient was determined in the stepwise regression analysis using the $t$-test with a probability level of $5 \%$ and only traits with a significant path coefficients were retained. In addition, spearman correlation analysis implemented in SAS v.9.4 [45] was done to determine the relationships among traits within the same order.

\section{Conclusions}

There was preponderance of additive gene action over non-additive one in the inheritance of grain yield under low-nitrogen and optimal environment conditions. The implication is that yield of maize hybrids under low-nitrogen and optimal environment conditions could be enhanced through recurrent selection and that inbred lines tolerant to low-nitrogen with high combining ability effects could be extracted from improved cycles of selection for hybrid development. Under CDHS environments, the non-additive 
gene action was more important than the additive gene action in the inheritance of grain yield implying that hybrid development should be employed under CDHS to exploit heterosis. Additionally, maternal effects influenced the inheritance of grain yield under CDHS environments. Plant aspect, ear aspect and ear height were identified as the primary traits contributing to the observed variations in grain yield under CDHS and low-nitrogen conditions. TZEQI 6 was identified as an inbred tester while hybrid TZEQI $113 \times$ TZEQI 6 was identified as a single-cross tester. This implied that TZEQI 6 could be used either as a male or a female parent in the production of high yielding hybrids while hybrid TZEQI $113 \times$ TZEQI 6 could be adopted as a single-cross tester for a three-way or double-cross hybrid production under low-nitrogen environments. Hybrids TZEQI $6 \times$ TZEQI 228 and TZEQI $210 \times$ TZEQI 188 should be tested extensively in on-farm trials and commercialized in SSA as combined low-nitrogen and CDHS tolerant hybrids.

Supplementary Materials: The following are available online at: https:/ / www.mdpi.com/article/ 10.3390/plants10122596/s1, Figure S1: Path analysis model diagrams showing inter-trait causal relationships of measured traits of early quality protein maize evaluated under low-nitrogen, combined drought, and heat and across test environments. Figure S2: Path analysis model diagrams showing inter-trait causal relationships of measured traits of early quality protein maize evaluated under low-nitrogen, combined drought and heat and across test environments. Figure S3: Monthly average temperature during the experimental period during dry season 2020 and 2021 at Kadawa, Nigeria. Table S1: North Carolina Design II mating design among 24 early quality protein maize inbred lines. Table S2: Daily minimum and maximum tempearture at Kadawa 2020 dry season. Table S3: Daily minimum and maximum tempearture at Kadawa 2021 dry season.

Author Contributions: Conceptualization, O.A.B., B.B.-A. and O.A.A.; methodology, O.A.B. and B.B.A.; supervision, B.B.-A., O.A.A. and A.L.O.; data analysis and manuscript draft, O.A.B.; manuscript review and editing, B.B.-A., O.A.A. and A.L.O. All authors have read and agreed to the published version of the manuscript.

Funding: This work was supported by the Bill \& Melinda Gates Foundation [OPP1134248] through the funding support to the Stress Tolerant Maize for Africa (STMA) Project.

Institutional Review Board Statement: Not Applicable.

Informed Consent Statement: Not Applicable.

Data Availability Statement: The datasets used in the present study have been deposited at the IITA CKAN repository.

Acknowledgments: The authors are grateful to the staff of the Maize Improvement Programme of IITA in Ibadan, Nigeria, for technical assistance.

Conflicts of Interest: The authors declare no conflict of interest.

\section{References}

1. FAOSTAT. Food and Agricultural Organization Statistical Database; FAO: Rome, Italy, 2017. Available online: http:// faostart.fao.org (accessed on 24 April 2021).

2. US Department of Agriculture (USDA). Foreign Agricultural Service. World Agricultural Production; Foreign Agricultural Service: Washington DC, USA, 2021. Available online: https://data.nal.usda.gov/dataset/world-agricultural-production (accessed on 15 November 2021).

3. CIMMYT; IITA. Maize — Global Alliance for Improving Food Security and the Livelihoods of the Resource-Poor in the Developing World; CIMMYT: El Batán, Mexico, 2010.

4. Badu-Apraku, B.; Fakorede, M.A.B. Advances in Genetic Enhancement of Early and Extra-Early Maize for Sub-Saharan Africa; Springer: Cham, Switzerland, 2017.

5. Sofi, P.A.; Wani, A.S.; Rather, A.G.; Wani, H.S. Review article: Quality protein maize (QPM): Genetic manipulation for the nutritional fortification of maize. J. Plant Breed Crop Sci. 2009, 1, 244-253. [CrossRef]

6. Tripathy, S.K.; Ithape, D.M.; Maharana, M.; Prusty, A.M. Quality Protein Maize (QPM): Genetic basis and breeding perspective. Trop. Plant Res. 2017, 4, 145-152. [CrossRef]

7. Akuamoah-Boateng, A. Quality Protein Maize Infant Feeding Trials in Ghana; Ghana Health Service: Accra, Ghana, 2002.

8. Mbuya, K.; Nkogolo, K.K.; Kalonji-Mbuyi, A. Nutritional analysis of quality protein maize varieties selected for agronomic characteristics in a breeding program. Int. J. Plant Breed Genet. 2011, 5, 317-327. [CrossRef] 
9. Panda, A.K.; Raju, M.V.L.N.; Rao, S.V.; Lavanya, G.; Reddy, E.; Sunder, G.S. Replacement of normal maize with quality protein maize on performance, immune response and carcass characteristics of broiler chickens. Asian Australas. J. Anim. Sci. 2010, 12, 1626-1631. [CrossRef]

10. Mageto, E.K.; Makumbi, D.; Njoroge, K.; Nyankanga, R. Genetic analysis of early maize (Zea mays L.) inbred lines under stress and nonstress conditions. J. Crop Improv. 2017, 4, 560-588. [CrossRef]

11. Obeng-Bio, E.; Badu-Apraku, B.; Ifie, B.E.; Danquah, A.; Blay, E.T.; Annor, B. Genetic analysis of grain yield and agronomic traits of early provitamin A quality protein maize inbred lines in contrasting environments. J. Agric. Sci. 2019, 157, 413-433. [CrossRef]

12. Ertiro, B.T.; Olsen, M.; Das, B.; Gowda, M.; Labuschagne, M. Efficiency of indirect selection for grain yield in maize (Zea mays L.) under low nitrogen conditions through secondary traits under low nitrogen and grain yield under optimal conditions. Euphytica 2020, 8, 134-146. [CrossRef]

13. Weber, V.S.; Melchinger, A.E.; Magorokosho, C.; Makumbi, D.; Bänziger, M.; Atlin, G.N. Efficiency of managed-stress screening of elite maize hybrids under drought and low nitrogen for yield under rainfed conditions in southern Africa. Crop Sci. 2012, 52, 1011-1020. [CrossRef]

14. Ray, D.K.; Gerber, J.S.; MacdoDonald, G.K.; West, P.C. Climatic variation explains a third of global yield variability. Nat. Commun. 2015, 6, 1-9. [CrossRef]

15. Cairns, J.E.; Crossa, J.; Zaidi, P.H.; Grudloyma, P.; Sanchez, C.; Araus, J.L.; Thaitad, S.; Makumbi, D.; Magorokosho, C.; Bänziger, M.; et al. Identification of drought, heat, and combined drought and heat tolerant donors in maize. Crop Sci. 2013, 53, 1335-1346. [CrossRef]

16. Anderson, R.; Bayer, P.E.; Edwards, D. Climate change and the need for agricultural adaptation. Curr. Opin. Plant Biol. 2020, 56, 197-202. [CrossRef]

17. Knox, J.; Hess, T.; Daccache, A.; Wheeler, T. Climate change impacts on crop productivity in Africa and South Asia. Environ. Res. Lett. 2012, 3, 34-43. [CrossRef]

18. Lobell, D.B.; Hammer, G.L.; McLean, G.; Messina, C.; Roberts, M.J.; Schlenker, W. The critical role of extreme heat for maize production in the United States. Nat. Clim. Chang. 2013, 3, 497-501. [CrossRef]

19. Shaw, S.B.; Mehta, D.; Riha, S.J. Using simple data experiments to explore the influence of non-temperature controls on maize yields in the mid-West and Great Plains. Clim. Chang. 2014, 4, 747-755. [CrossRef]

20. Carter, E.K.; Melkonian, J.; Riha, S.J.; Shaw, S.B. Separating heat stress from moisture stress: Analyzing yield response to high temperature in irrigated maize. Environ. Res. Lett. 2016, 9, 094012. [CrossRef]

21. Meseka, S.; Menkir, A.; Bossey, B.; Mengesha, W. Performance Assessment of Drought Tolerant Maize Hybrids under CDHS. Agronomy 2018, 12, 274. [CrossRef] [PubMed]

22. Nelimor, C.; Badu-Apraku, B.; Tetteh, A.Y.; N'guetta, A.S.P. Assessment of Genetic Diversity for Drought, Heat and CDHS Tolerance in Early Maize Landraces. Plants 2019, 11, 518. [CrossRef]

23. Nelimor, C.; Badu-Apraku, B.; Tetteh, A.Y.; Garcia-Oliveira, A.L.; N'guetta, A.S.P. Assessing the Potential of Extra-Early Landraces for Improving Tolerance to Drought, Heat, and Both Combined Stresses in Maize. Agronomy 2020, 3, 318. [CrossRef]

24. Chiuta, N.E.; Mutengwa, C.S. Combining Ability of Quality Protein Maize Inbred Lines for Yield and Morpho-Agronomic Traits under Optimal as Well as Combined Drought and Heat-Stressed Conditions. Agronomy 2020, 2, 184. [CrossRef]

25. Neate, P. Climate-Smart Agriculture Success Stories from Farming Communities around the World; CGIAR Research Program on Climate Change; Agriculture and Food Security (CCAFS); Technical Centre for Agricultural and Rural Cooperation (CTA): Wageningen, The Netherlands, 2013.

26. Badu-Apraku, B.; Fakorede, M.A.B.; Talabi, A.O.; Oyekunle, M.; Akaogu, I.C.; Akinwale, R.O.; Annor, B.; Melaku, G.; Fasanmade, Y.; Aderounmu, M. Gene action and heterotic groups of early white quality protein maize inbreds under multiple stress environments. Crop Sci. 2016, 56, 183-199. [CrossRef]

27. Cairns, J.E.; Sonder, K.; Zaidi, P.H.; Verhulst, N.; Mahuku, G.; Babu, R.; Prasanna, B.M. Maize Production in a Changing Climate. Adv. Agron. 2012, 114, 1-58. [CrossRef]

28. Oyetunde, O.A.; Badu-Apraku, B.; Ariyo, O.J.; Alake, C.O. Efficiencies of Heterotic Grouping Methods for Classifying Early Maize Inbred Lines. Agronomy 2020, 8, 1198. [CrossRef]

29. Nasser, L.M.; Badu-Apraku, B.; Gracen, V.E.; Mafouasson, H.N.A. Combining ability of early yellow maize inbreds under CDHS and well-watered environments. Agronomy 2020, 10, 1585. [CrossRef]

30. Ifie, B.E.; Badu-Apraku, B.; Gracen, V.; Danquah, E.Y. Genetic analysis of grain yield of IITA and CIMMYT early maize inbreds under Striga-infested and low-soil-nitrogen environments. Crop Sci. 2015, 55, 610-623. [CrossRef]

31. Annor, B.; Badu-Apraku, B. Gene action controlling grain yield and other agronomic traits of extra-early quality protein maize under stress and non-stress conditions. Euphytica 2016, 212, 213-228. [CrossRef]

32. Abu, P.; Badu-Apraku, B.; Ifie, B.E.; Tongoona, P.; Ribeiro, P.F.; Obeng-Bio, E.; Offei, S.K. Genetics of extra-early yellow and orange quality-protein maize (QPM) inbreds and derived hybrids under low-soil nitrogen and Striga-infestation. Crop Sci. 2020, 61, 1052-1078. [CrossRef] [PubMed]

33. Makumbi, D.; Betrán, F.J.; Bänziger, M.; Ribaut, J. Combining ability, heterosis and genetic diversity in tropical maize (Zea mays L.) under stress and non-stress conditions. Euphytica 2011, 180, 143-162. [CrossRef] 
34. Noëlle, M.A.H.; Richard, K.; Vernon, G.; Martin, Y.A.; Laouali, M.N.; Liliane, T.N.; Godswill, N.N. Combining Ability and Gene Action of Tropical Maize (Zea mays L.) Inbred Lines under Low and High Nitrogen Conditions. J. Agric. Sci. 2017, 9, 222-235. [CrossRef]

35. Baker, R.J. Issues in diallel analysis. Crop Sci. 1978, 18, 533-536. [CrossRef]

36. Pswarayi, A.; Vivek, B.S. Combining ability amongst CIMMYT's early maize (Zea mays L.) germplasm under stress and non-stress conditions and identification of testers. Euphytica 2008, 162, 353-362. [CrossRef]

37. Oyekale, S.A.; Badu-Apraku, B.; Adetimirin, V.O. Combining ability of extra-early biofortified maize inbreds under Striga infestation and low soil nitrogen. Crop Sci. 2020, 60, 1925-1945. [CrossRef]

38. Badu-Apraku, B.; Oyekunle, M.; Fakorede, M.A.B.; Vroh, I.; Akinwale, R.O.; Aderounmu, M. Combining ability, heterotic patterns and genetic diversity of extra-early yellow inbreds under contrasting environments. Euphytica 2013, 192, 413-433. [CrossRef]

39. Derera, J.; Tongoona, P.; Vivek, B.S.; Laing, M.D. Gene action controlling grain yield and secondary traits in southern African maize hybrids under drought and non-drought environments. Euphytica 2008, 162, 411-422. [CrossRef]

40. Girma, C.H.; Sentayehu, A.; Berhanu, T.; Temesgen, M. Test cross performance and combining ability of maize (Zea mays L.) inbred lines at Bako, Western Ethiopia. Global J. Sci. Front. Res. D Agric. Vet. 2015, 15, 1-26.

41. Terron, A.; Preciado, E.; Cordova, H.; Mickelson, H.; Lopez, R. Determinacion del patron heterotico de 30 line as de maizderivadas de la poblacion SR del CIMMYT. Agron. Mesoam. 1997, 43, 26-34.

42. Talabi, A.O.; Badu-Apraku, B.; Fakorede, M.A.B. Genetic variances and relationship among traits of an early maize population under drought-stress and low nitrogen environments. Crop Sci. 2017, 57, 681-692. [CrossRef]

43. Badu-Apraku, B.; Akinwale, R.O.; Franco, J.; Oyekunle, M. Assessment of reliability of secondary traits in selecting for improved grain yield in drought and low-nitrogen environments. Crop Sci. 2012, 52, 2050-2062. [CrossRef]

44. Comstock, R.E.; Robinson, H.F. The components of genetic variance in population of biparental progenies and their use in estimating the average degree of dominance. Biometrics 1948, 4, 254-266. [CrossRef]

45. SAS Institute Inc. SAS User's Guide: Statistics, version 9.4; SAS Institute Inc.: Cary, NC, USA, 2017.

46. Hallauer, A.R.; Miranda, J.B. Quantitative Genetics in Maize Breeding, 2nd ed.; Iowa State University Press: Ames, IA, USA, 1988.

47. Fehr, W. Principle of Cultivar Development; Macmillian Publishing Company: New York, NY, USA, 1991; Volume 1, p. 2.

48. Falconer, D.S.; Mackay, T.F.C. Introduction to Quantitative Genetics, 4th ed.; Longman: New York, NY, USA, 1996.

49. Singh, R.K.; Chaudhary, B.D. Biometrical Methods in Quantitative Genetic Analysis; Kalyani Publisher: New Delhi, India, 1985.

50. Cox, J.; Frey, K.J. Combining ability and the selection of parents for specific oat mating. Crop Sci. 1984, 24, 963-967. [CrossRef]

51. Badu-Apraku, B.; Fakorede, M.A.B.; Oyekunle, M.; Akinwale, R.O. Selection of extra-early maize inbreds under low N and drought at flowering and grain-filling for hybrid production. Maydica 2011, 56, $29-41$.

52. Yan, W. GGE biplot-A windows application for graphical analysis of multi environment trial data and other types of two-way data. Agron. J. 2001, 93, 1111-1118. [CrossRef]

53. Yan, W.; Kang, M.S.; Ma, S.; Woods, S.; Cornelius, P.L. GGE biplot vs. AMMI analysis of genotype-by-environment data. Crop Sci. 2007, 47, 643-653. [CrossRef]

54. Pacheco, A.; Vargas, M.; Alvarado, G.; Rodríguez, F.; Crossa, J.; Burgueño, J. GEA-R (Genotype $\times$ Environment Analysis with R for Windows); Version 2.0.; CIMMYT: El Batán, Mexico, 2016.

55. Mohammadi, S.A.; Prasanna, B.M.; Singh, N.N. Sequential path model for determining interrelationships among grain yield and related characters in maize. Crop Sci. 2003, 43, 1690-1697. [CrossRef]

56. Statistical Package for Social Sciences (SPSS), Inc. SPSS Base 17.0 for Windows User's Guide; SPSS Inc.: Chicago, IL, USA, 2007. 